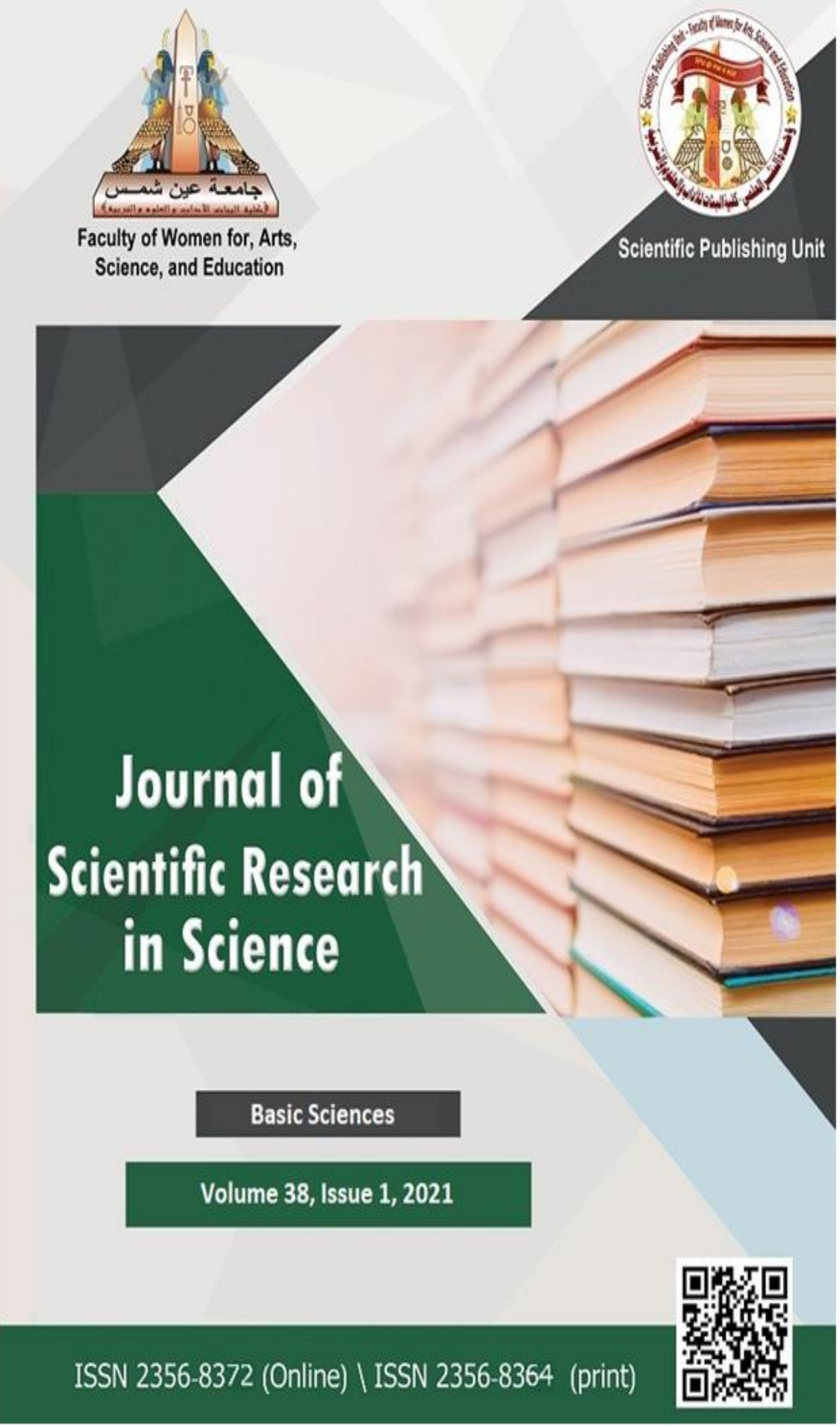




Journal of Scientific Research in Science

\title{
Construction of a New Method for Easy Fitting Block Pattern uitable for Egyptian Women and Comparing it to the Borgo Method
}

\author{
Haneen Mahmoud *, Khaled M. A. Abdo, Heba Z. Abou Hashish \\ Home Economics Department, Faculty of Women for Arts, Science and Education, \\ Ain Shams University
}

\begin{abstract}
:
Constructing a basic block pattern is an essential step that covers all body types, and therefore can be applied to any design and any type of clothing. This means, constructing a suitable basic block pattern increases the quality of the pieces of clothes. So, it calls for the technical side in the analysis of the design accurately and understand the type and construction of fabric used, and between the practical side in taking the body measurements accurately and add the appropriate ease amount of comfort for a good fitting for all sizes, and gives the appropriate effect in terms of fit, comfort, and drape. Therefore, the aim of the research focused on constructing an easy-fitting block pattern of the blouse to suit the body of the Egyptian woman. The results showed that the new suggested method is better than the method of Fernando Borgo (B) as such, the study recommended the importance of studying the easy fitting block and studying the pattern making as one of the main factors for the quality of the final product.
\end{abstract}

\section{Keywords:}

Easy fitting pattern, Block pattern, Pattern making, Body measurements, Borgo method

\section{Introduction}

The easy fitting block pattern is one of the most important and usually used patterns in ready-made garment factories, it characterized by not exactly fitted on the body and characterized also by increasing in the added amount of basic ease, moreover it can be created in an easy way, which helps to produce rapid designs to save time and effort and produce different and more innovative designs.

Fitting is one of the main concerns of the clothing industry, the accurate body measurements, and development patterns making are needed to deliver well-fitting garments. Therefore, many academic studies seek to improve the final product through development in the process of taking measurements and developing the used patterns and thus improve the level of the fitting. Consequently, the purpose of this research is 
to construct an easy fitting block pattern to enhance the fit and to suit the Egyptian woman's body.

The researcher was exposed to all research that has a direct relationship with the research topic, which are:

A. A study entitled "Introduction of a new method for constructing the basic pattern for women by comparing three methods, 2014 [28]. This research aims to construct a basic pattern for women through identifying the best way of three methods (American McDonalds, Italian Burgo, English Aldrich) in terms of the proportion of comfort, fit, and general form. In addition to the development of a new suggested method to construct a basic pattern for women in which the advantages of the three methods are available to suit the nature of the Egyptian women's body. This research followed the experimental method and the sample consisted of three sizes: $(40-44-$ 48), where nine samples were carried out. The results showed that the best method for sizes (44-48) is the American method McDonald's, while the best method for size (40) is the English method Aldrich, however, The Italian method Burgo showed the less ratios of all sizes. Moreover, reaching to a new method of a basic pattern (Blouses) through the advantages of the three methods. This study has a direct relationship with the research because it creates a new method for constructing a pattern for women by comparing three methods (American McDonalds, Italian Burgo, English Aldrich).

B. A study entitled "A comparative study between Profili and Helen Armstrong Patterns and to make use of them in the implementation of the Egyptian women's jacket, 2018 [3]. This study aims to construct a basic Pattern Women`s Jacket to achieve good fitting factors, to suit the Egyptian woman's body. This research followed the descriptive-analytical method and experimental method. The sample consisted of three different sizes: $(36-40-44)$. The results showed that the Helen pattern method after Modification gave high degrees than the Profile method where it achieved the rate of $100 \%$ in Balance and fitting in all sizes so that it suitable for different Egyptian's body. While the Profili method ratios are high only for the smallest size, and the ratios were less when the sizes are increased. And this research is directly related to the research subject. This study has a direct relationship to the research because it is a comparative study between two methods of making the jacket and use of them in implementing a jacket to suit Egyptian women, and the current study also 
concerned that the suggested method fits the Egyptian women's body through a comparison also between two methods.

C. A study entitled "A Study on corsage of women darts free basic model design methods", 2018 [25]. This study aims to try to reach the best and simplest way to get a basic block pattern of Corsage without darts. The research followed the applied experimental method for its suitability for achieving the research objectives. The sample consisted of mannequins of various sizes $(46,50,42)$

The most important results of the study were the existence of statistically significant differences between the mean degrees of controlling the model by the method (A) (Aldrich method - to construct the block pattern of corsage without darts for women), the method (B) (the flat model, the method of Dr. Muhammad Al-Badri, Dr. Muhammad Al-Sayed Hassan) and the method (c) (the proposed method for constructing the basic pattern without darts corsage for women) for the sizes $(42,46$, 50). Moreover the statistically significant showing differences between the three methods of constructing the basic block pattern without dart of the proposed method (C) Better in achieving the aspects in terms of (the fabric grain, lines, the amount of ease, and the general shape) of evaluation, followed by method (B), then followed by the method (A) for the sizes $(42,46,50)$. This study has a direct relationship to the research because it is a comparative study between two methods of constructing the pattern without darts, and among the methods is for (Aldrich method to construct the block pattern of corsage without darts for women), and it is among the methods used in this research used in the comparison.

The aim of this research is to construct an easy fitting block pattern for more accurate and appropriate fitting of Egyptian women's bodies. This research is limited to study the body measurements of Egyptian women from the age of 18-23 years and to construct a new suggested method for easy fitting block pattern that fits the the Egyptian women's body.

\subsection{Research Definitions}

Easy fitting block pattern: is also named the dart-less block, and is suitable for all loose-fitting garments. [31, 9] 
Block pattern: it referred to as sloper pattern, basic pattern, and master pattern. it is a foundation pattern that has no design lines or seam allowances, and it a basis for pattern development. [31, 1, 20]

\subsection{Body measurements}

The accurate body measurements are a prerequisite for obtaining a successful construction pattern, either by hand-drafted pattern or computer-generated. And as well, good measurements are responsible for everything concerning pattern making and pattern grading.

The understanding of measurements is important for a pattern maker to understand the proportions of the body to develop patterns that have style details and especially those not located on standard landmarks of the body. Moreover, to develop the block pattern, by knowing the dimensional principles controlling the construction of block pattern. [7, 11,27]

\subsubsection{General rules for taking body measurements}

The measurements must be taken with the greatest degree of accuracy. There are a few precautions that must take into account when taking measurements, to ensure obtaining the most accurate results:

1. The loose or thick clothes will increase the measurements so measuring must usually over the tight-fitting clothes.

2. The body measurements and body shape can be affected by the different undergarments so the usual undergarments must be worn.

3. A narrow ribbon must be tied around the natural waistline before measuring, and it must be parallel to the ground to obtain a guide for vertical measurements.

4. The person being measured must be stand up in a straight and relaxed position.

5. Measuring the circumference should be neither loose nor tight. (can place two fingers behind the tape measure comfortably). And round the measurement number to the nearest integer. [2, 26, 23]

\subsection{Pattern making}

Pattern making: is a $2 \mathrm{D}$ or $3 \mathrm{D}$ process, that converts the drawing stage to garment production, by shaping the fabric to conform to the human figures.[7] 


\subsubsection{Patternmaking methods}

Three different patternmaking methods varying in presentation, details, and the methods of construction are:

A. Draping method: Often called the 'Modelling method' is creating threedimensional pieces of the pattern by the fabric directly pinned to a Mannequin. $[6,13]$

B. Drafting pattern: is the most mechanical method of pattern development, it can be constructed by drafting manually or produced by a computer programmed. Therefore, it is more used for staple ready-to-wear.

C. Flat pattern: is creating patterns by manipulating and alter the basic block into more sophisticated patterns. It is created by using the drafting method or draping method. $[31,11]$

\subsubsection{Borgo method}

It is the (Italian method) of the author Fernando Borgo, which appeared during the year 1992.[4] This method is considered as drafting patternmaking method, constructing depends on many and different measurements these are height, size which determines by the (full chest measurement /2), back waist length, front waist-length, back width, and back shoulder width. Fig. $(1,2)$ Showing the block pattern and sleeve block pattern of the Borgo method. [6] 


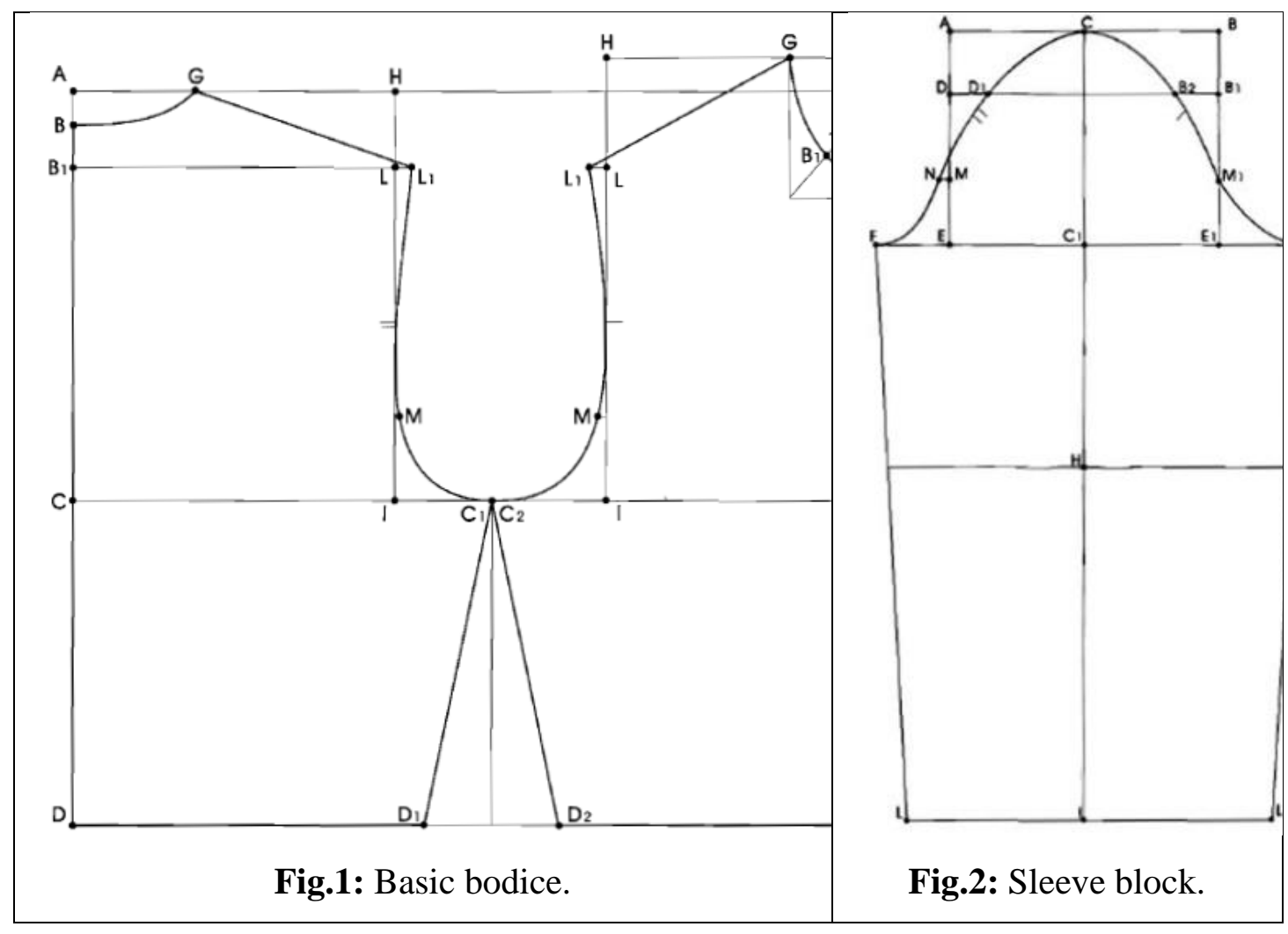

\subsection{The Concept of Clothing Fit:}

Clothing fit refers to that hangs smoothly and evenly on the body without wrinkles, pulls or deformation of the fabric, straight seams, pleasing proportions, suitable ease for movement to perform normal activates $[14,18]$. So, the clothing fit has definite in multiple dimensions to understand the meaning of fit overall. Fit is defined as a combination of the main five factors grain, line, ease, balance, and set[10,15]. A problem of the clothing fit (ill-fitting) appears from insufficient product development, which starts from pattern development, selection of a fit model (the variety in our bodies because we all have individual unique bodies), grading, and distortion of grain line. [24]

\subsubsection{Fit Test and Standard}

Standard of fit: This is a set of criteria, which include all parts of the garment that should be examined to measure the garment fit.

Dress forms and live models are the common standards used through wear trials to test clothing fit, and it is judged by the assessors. They are using the evaluation fit scheme which contains different points, it will provide to assess whether the garment can fit the model accurately, smoothly, and comfortably, also whether the garment seams follow the natural line of the garment, and allows the body free movements.[18] 
The fitting scheme for a bodice block, the construction of the bodice is analyzed under the following:

Bust position and average fitting allowance: The bust and chest area must be smooth without wrinkles, moreover, must have appropriate ease to allow the body movement. If the garment is too small, the closures are going to pull and gape open. The bust line may appear as a diagonal line from the bust area to the side seam and can correct it by loosening the width pattern at the center front and sometimes by adding a bust dart to taking the surplus and achieve a more hanging fit of the front. [19]

Back and average fitting allowance: The back must appear smooth without drags. The drags are the result of tightness or shortness of the garments between two points. The horizontal wrinkles if across the back is tight. On the other hand, vertical wrinkles occur in the back when the waist length is too short.

Waist position and average fitting allowance: the narrowest must fall at the wearer's waist It should have the comfort to free-moving, breathing, and seating. Horizontal wrinkles or a common looseness of the back above the waist may because of the too length of the back waist so it requires shortening the back to correct it (pulling it up). [19, 21,14]

Hip position and average fitting allowance: The widest part of the blouse must fall at the wearer's hip, it should have the comfort to free-moving, and seating. The tightness in the hips area cause wrinkles in it and the middle of the back also can affect the waist and can correct it by loosening the width pattern of the hip at the sides.

Shoulder slop and position: Should appear smooth. The shoulder slope of the garment must parallel exactly to the shoulder slope of the body and must lie on the top, at the middle of the shoulder un-tilted forward or backward

Neck-line width and shape: The good neck fitting should lie flat around the front and back neck. the width of the back neckline controls the position of the shoulder point and the front neckline. and always the front neckline depth is lower than the back neckline depth. $[16,19,21]$

Armhole shape, depth, and position: The armscye should fit well on the body without wrinkles to be comfortable and attractive. armscye circumference should be suitable, not tightness so it will pull at the front and back of the garment and not lose 
that will gape the garment. Armscye should be at the back is less deep than at the front because the movements are in the front. [19, 29,22]

\section{Experimental Work}

\subsection{Research tools}

1. Questionnaire sheet: to evaluate the methods. (The questionnaire sheet was used for the first modified suggested method and the remodifying of the modified suggested method).

2. Egyptian Women Table of Measurements. [5]

3. Photographs of sample members.

4. IBM SPSS Statistics 27.0.1.0

\subsection{Research procedures}

This research aimed to construct a new suggested easy fitting block Pattern suitable for Egyptian women's body and comparing it with Borgo method, and the research steps were as follows:

\subsubsection{Choosing the basic sample.}

The researcher chose samples from the Women's college because it includes students from different Egyptian governorates and therefore will cover the study in different bodies and sizes.

The basic samples were chosen from the random samples to be closest to the table measurements of Egyptian specifications, Then the samples were divided into four groups (A, B, C, D) with different sizes small, medium, large and x-large. Table [1] shows the four size samples [5]. 
Table [1]: The measurements of the four basic samples (S, M,L, and XL).

\begin{tabular}{|c|c|c|c|c|c|c|c|c|c|c|c|c|c|c|c|c|}
\hline $\begin{array}{l}\mathrm{Siz} \\
\mathrm{e}\end{array}$ & Height & $\begin{array}{l}\text { Nec } \\
k\end{array}$ & $\begin{array}{l}\text { Chest } \\
\text { Circ. }\end{array}$ & $\begin{array}{l}\text { Bust } \\
\text { Circ. }\end{array}$ & $\begin{array}{l}\text { Waist } \\
\text { Circ. }\end{array}$ & $\begin{array}{l}\text { Hip } \\
\text { Circ. }\end{array}$ & $\begin{array}{l}\text { Chest } \\
\text { Width }\end{array}$ & $\begin{array}{l}\text { Back } \\
\text { Width }\end{array}$ & $\begin{array}{l}\text { Back } \\
\text { Shoulder } \\
\text { Width }\end{array}$ & $\begin{array}{l}\text { Shoulder } \\
\text { Length }\end{array}$ & $\begin{array}{l}\text { Front } \\
\text { waist } \\
\text { lengt } \\
\text { h }\end{array}$ & $\begin{array}{l}\text { Back } \\
\text { waist } \\
\text { lengt } \\
\text { h }\end{array}$ & $\begin{array}{l}\text { Nap } \\
\text { eto } \\
\text { waist }\end{array}$ & $\begin{array}{l}\text { Waist } \\
\text { tohip }\end{array}$ & $\begin{array}{l}\text { Arm } \\
\text { hole } \\
\text { dept } \\
\text { h }\end{array}$ & $\begin{array}{l}\text { Sleeve } \\
\text { length }\end{array}$ \\
\hline $\mathbf{S}$ & 164 & 35 & 92 & 93 & 76 & 100 & 33 & 36.5 & 38 & 13 & 42.5 & 41 & 40 & 20 & 21.5 & 59 \\
\hline $\mathbf{M}$ & 165 & 37 & 98 & 100 & 84 & 110 & 37 & 39 & 41.5 & 13.5 & 43 & 42 & 41 & 18 & 23 & 60 \\
\hline $\mathbf{L}$ & 158 & 39 & 106 & 108 & 92 & 116 & 38 & 40 & 42 & 14 & 42 & 41.5 & 40 & 18 & 23.5 & 58 \\
\hline XI & 158 & 41 & 112 & 115 & 101 & 123 & 395 & 42 & 44 & 15 & 43 & 41.5 & 40 & 18 & 24 & 60 \\
\hline
\end{tabular}

\subsubsection{Constructing a new suggested block pattern to suit the Egyptian womrn's body.}

The researcher constructing a new suggested method of easy fitting block pattern suitable to Egyptian women's body by used different measurements and equations.

\subsubsection{Preparing a questionnaire sheet to evaluate the suggested method.}

The evaluation of the block pattern is done after designed an evaluation form carried out according to the basic criteria of the blouse and to measure the accuracy and fitting of the samples for the suggested pattern. The questionnaire sheet entitled (Questionnaire sheet for the accomplishment of constructed easy fitting block patterns). It was prepared, and divided into three sections which are front, back, and sleeve. And Appendix No. (1) shows the final form of the questionnaire sheet and was corrected by three of the arbitrators by using the assessment scale in the evaluation process and each corrector made the evaluation process alone. 
The correlation coefficient between the three grades corrected by the correctors $(\mathrm{X}, \mathrm{Y}, \mathrm{P})$ was calculated for the post-application test using the grade correlation coefficient for each sample separately. The following table [2] shows this:

Table [2]: The Correlation coefficient between the correctors

\begin{tabular}{c|c|c|c|c}
\hline Correctors & Front & Back & Sleeve & Total \\
\hline B · A & 0.803 & 0.726 & 0.851 & 0.824 \\
\hline C · A & 0.755 & 0.894 & 0.908 & 0.792 \\
\hline C · B & 0.917 & 0.839 & 0.773 & 0.873 \\
\hline
\end{tabular}

The above table shows the high values of correlation coefficients between the correctors, and all the values are significant at the level of 0.01 for proximity to number one, indicating the reliability of the estimation scale.

\subsubsection{Evaluating this suggested easy fitting block pattern.}

The construction of the new method suggested pattern was drawn with long sleeves accurately for the same four sizes (S, M, L, and XL), and was reviewed to make sure there are no mistakes. Then the four samples were scientifically cut on the muslin fabric. And the evaluation of the samples was carried out by wearing each sample. See fig. (3)

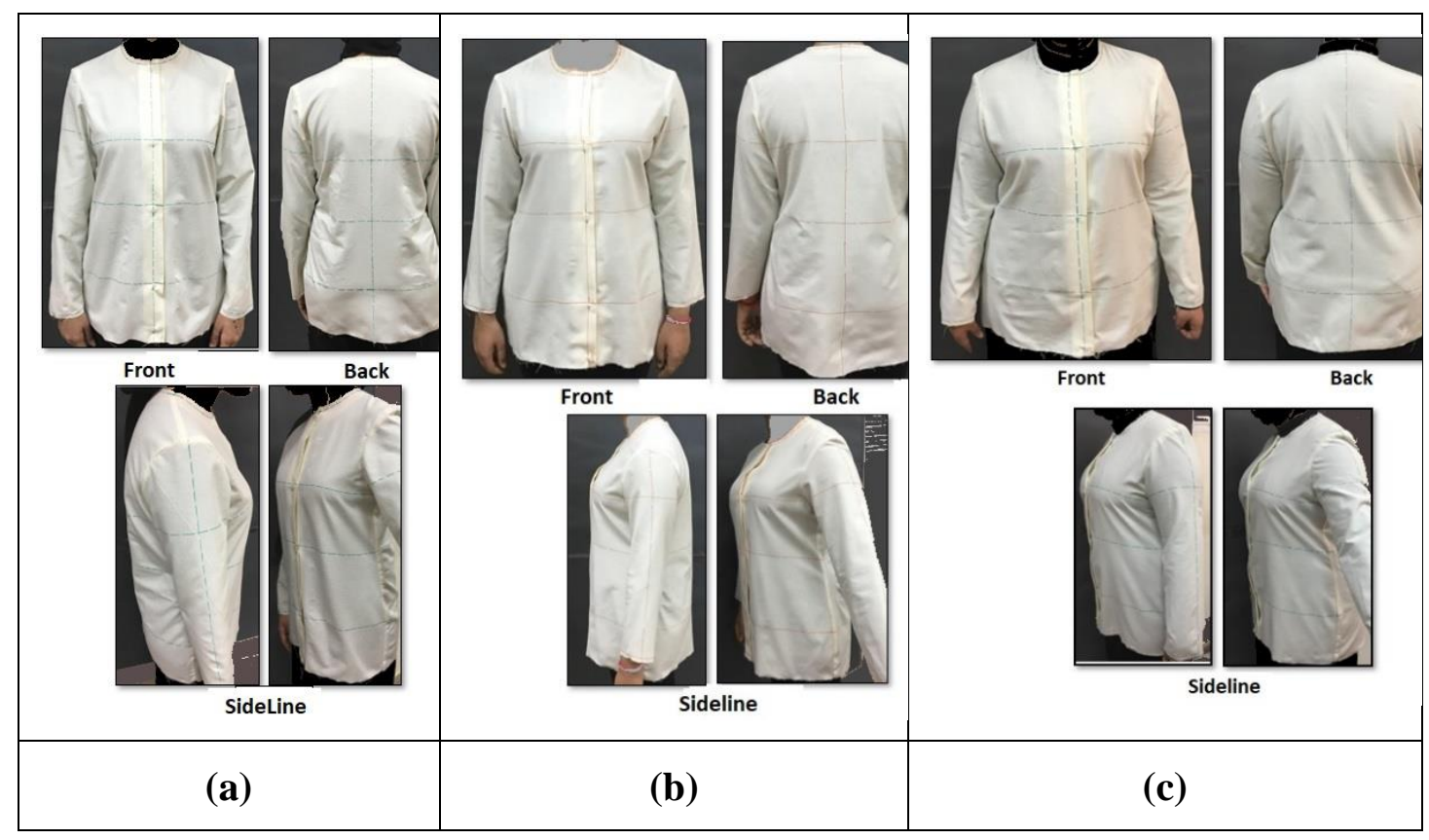

Fig.3: Fitting samples of the suggested pattern: (a) size "S", (b) size "M", (c) size "L". 
This figure showing the suggested pattern was evaluated and appeared that have appropriate ease for the easy fitting blouse. On the front side, the chest area showed smoothness without wrinkles, but there are diagonal lines from the bust area to the side seam. Moreover, the backside showed diagonal lines from the shoulder blade area to the side. The waist and hip areas were showed smoothness without wrinkles. The front and back neck lied flat without pulling against the body and the width and the depth were fitted well. The shoulder appears smooth but it lied tilted backward. The armscye fit well, the sleeve having diagonal wrinkles on the top of the shoulder around the arm in front and back. So that, the pattern needeed modifications to adjust the fitting and showed the blouse with a good overall appearance.

\subsubsection{Re-modifying the suggested method.}

After reviewing the samples of the first suggested pattern, we modified the pattern to get a better and accurate result and appropriate fitting with Egyptian women's body.

\subsubsection{Re-evaluating the suggested method.}

The two methods were evaluated which Borgo (B) (Italian method) and the (Suggested method) carried out by fitting a muslin sample to the targeted model. See fig. (4-11).

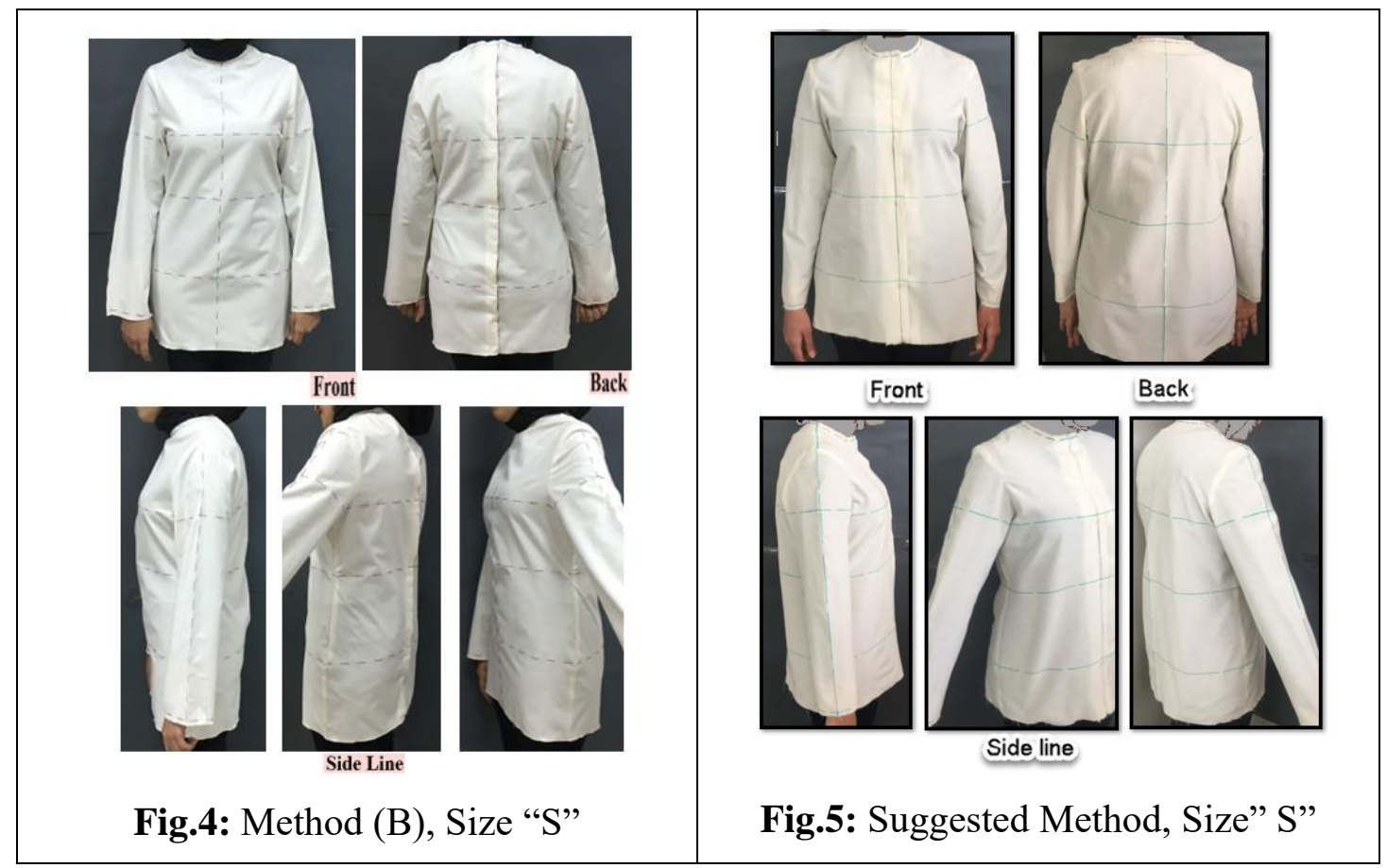




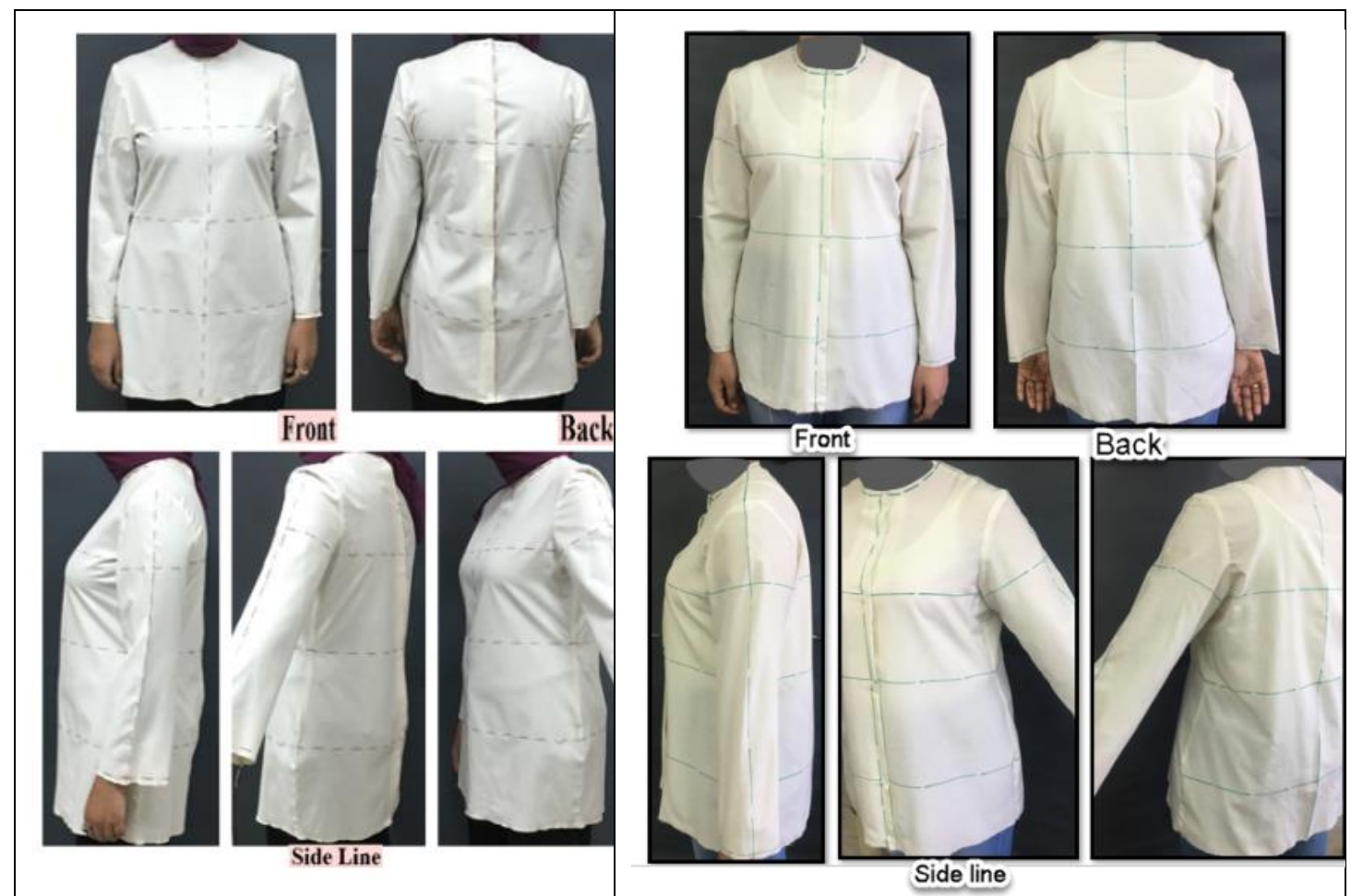

Fig.6: Method (B), Size "M"

Fig.7: Suggested Method, Size "M"

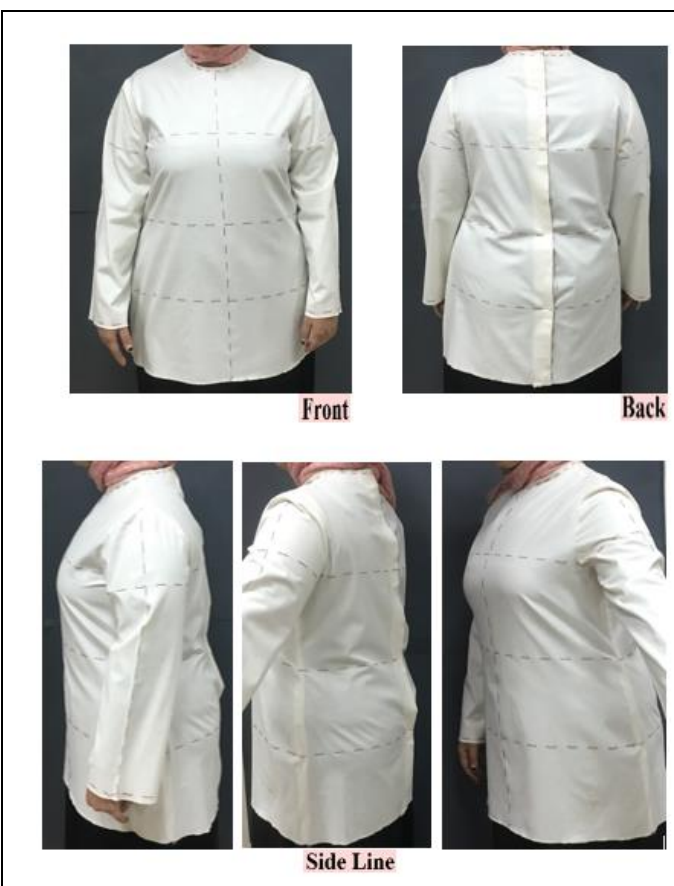

Fig.8: Method (B), Size "L"
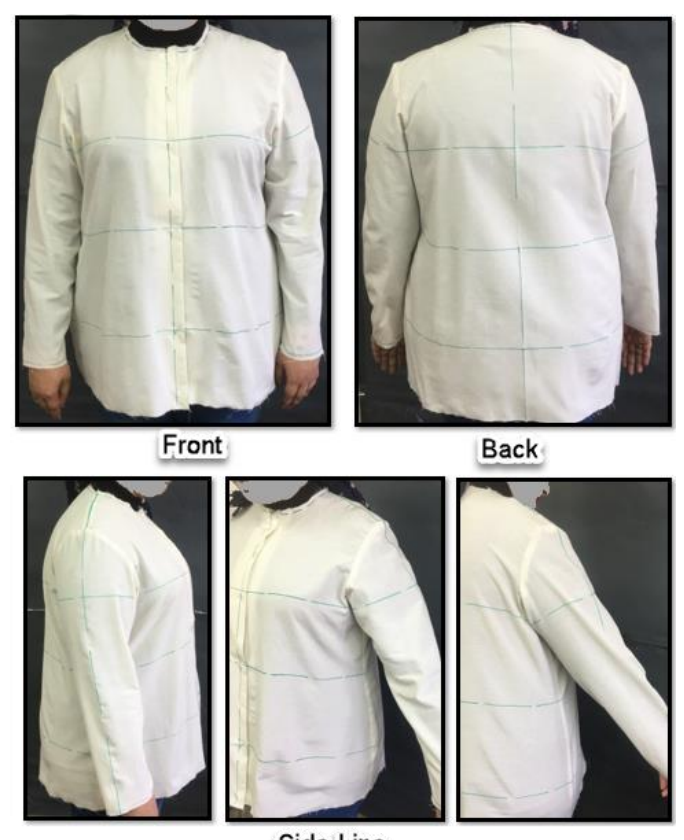

Side Line

Fig.9: Suggested Method, Size "L" 


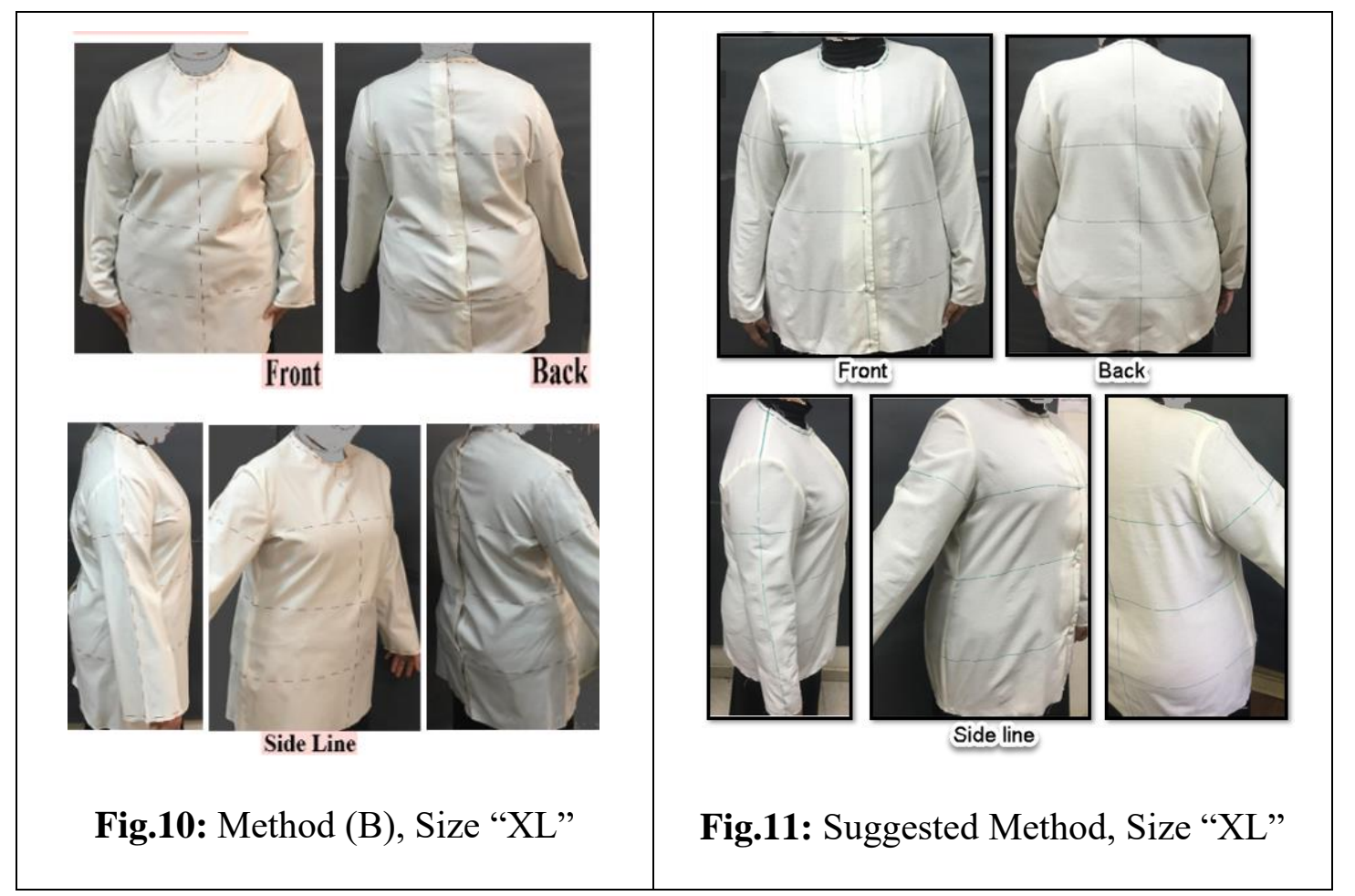

\section{Results:}

\subsection{The first assumption:}

There are statistically significant differences between the averages of the Specialists 'opinions of the two methods in the front for the measurements used S, M, $\mathrm{L}$, and XL".

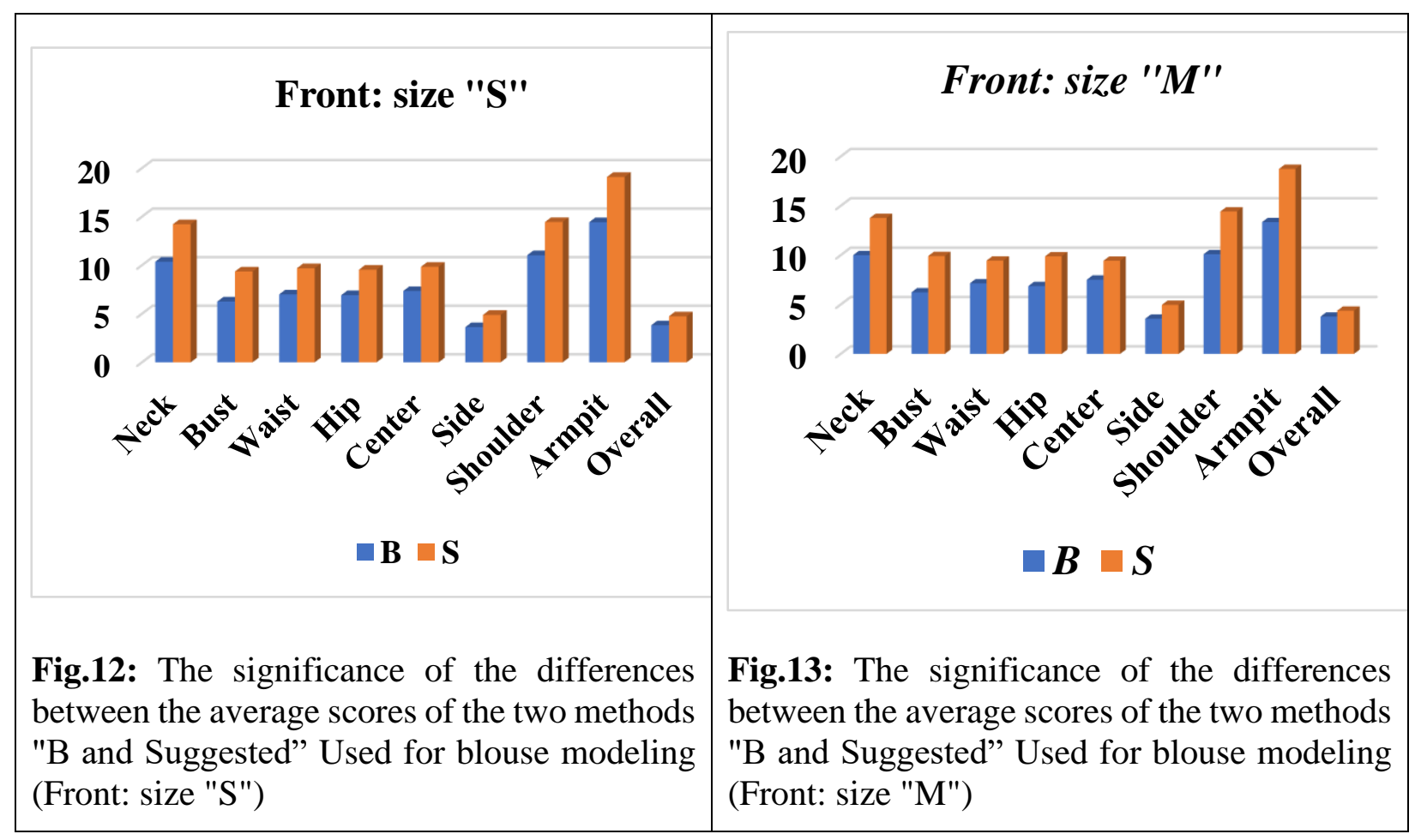




\begin{tabular}{|l|l|}
\hline \multicolumn{1}{|c|}{ Front: size "L" } & Front: size "XL" \\
\hline
\end{tabular}


Table [3]: The differences between the averages of the specialists 'opinions of the two methods in the front for the measurements used S, M, L, and XL".

\begin{tabular}{|c|c|c|c|c|c|c|c|c|c|c|c|c|c|c|c|c|c|}
\hline & \multicolumn{2}{|c|}{ Front } & \multicolumn{3}{|c|}{ Mean } & \multicolumn{4}{|c|}{ Std. Deviation } & \multicolumn{4}{|c|}{ T-test } & \multicolumn{4}{|c|}{ Significant } \\
\hline \multicolumn{2}{|l|}{ हैं } & $n$ & $\Sigma$ & 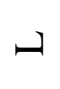 & $\bar{x}$ & $n$ & $\Sigma$ & 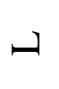 & $\bar{x}$ & $n$ & $\Sigma$ & 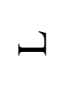 & $\bar{x}$ & is & $\Sigma$ & 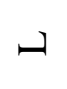 & $\not$ \\
\hline \multirow{2}{*}{$\begin{array}{l}\frac{\mathscr{Z}}{8} \\
\frac{8}{8} \\
z\end{array}$} & $\varphi$ & గొ & 은 & $\stackrel{\infty}{\stackrel{0}{0}}$ & 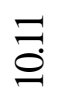 & i & nิ & $\ddot{n}$ & $\stackrel{\sqrt[n]{7}}{7}$ & \multirow{2}{*}{$\tilde{\hbar}$} & \multirow{2}{*}{$\overbrace{\infty}$} & \multirow{2}{*}{ டి. } & \multirow{2}{*}{ ণ্ } & \multirow{2}{*}{$\bar{\sigma}$} & \multirow{2}{*}{ 뭉. } & \multirow{2}{*}{ 뭉. } & \multirow{2}{*}{$\bar{\delta}$} \\
\hline & $\Omega$ & さ્ & $\stackrel{\infty}{\stackrel{\infty}{\sigma}}$ & $\stackrel{\text { ㄱ. }}{ \pm}$ & $\stackrel{n}{ \pm}$ & 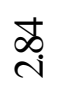 & $\underset{\dot{d}}{\mathbb{d}}$ & $\tilde{m}$ & $\frac{n}{n}$ & & & & & & & & \\
\hline \multirow{2}{*}{ 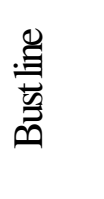 } & $\varphi$ & สู & đู & 3 & $\frac{n}{n}$ & $\underset{i}{\sim}$ & $\bar{m}$ & તิ & तิ & \multirow{2}{*}{ 8) } & \multirow{2}{*}{$\stackrel{\infty}{\stackrel{\infty}{f}}$} & \multirow{2}{*}{$r$} & \multirow{2}{*}{$\overrightarrow{\widehat{\lambda}}$} & \multirow{2}{*}{$\bar{\delta}$} & \multirow{2}{*}{$\bar{\varnothing}$} & \multirow{2}{*}{$\bar{\varnothing}$} & \multirow{2}{*}{$\stackrel{2}{8}$} \\
\hline & $\sim s$ & $\tilde{a}$ & ๙ু & $\frac{n}{a}$ & $\stackrel{7}{a}$ & 고 & $\stackrel{\mathscr{r}}{\mathrm{i}}$ & 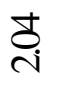 & $\stackrel{\mathscr{f}}{\mathrm{i}}$ & & & & & & & & \\
\hline \multirow{2}{*}{ 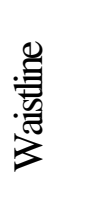 } & $\infty$ & $r$ & $\frac{n}{\pi}$ & ஓे & 뭉 & ปิ & กิ & ชి & กิ & \multirow{2}{*}{$\sqrt[n]{n}$} & \multirow{2}{*}{$\sqrt{n}$} & \multirow{2}{*}{ તิ } & \multirow{2}{*}{$\underset{i}{\mathbb{Z}}$} & \multirow{2}{*}{ ?ִ } & \multirow{2}{*}{ ?ִ } & $\curvearrowleft$ & \\
\hline & $\Omega$ & ชे & ఫ̊ & $\stackrel{\wp}{\curvearrowleft}$ & $\frac{n}{a}$ & $\underset{\mathrm{i}}{\mathrm{i}}$ & $\underset{i}{\sigma}$ & $\stackrel{\text { I }}{\mathrm{J}}$ & ชె & & & & & & & 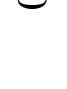 & \\
\hline $\mathscr{\Xi}$ & $\varphi$ & హ్ & $\begin{array}{l}\infty \\
\infty \\
\infty\end{array}$ & $\frac{8}{r}$ & $\mathscr{0}_{0}$ & $\underset{i}{\mathbb{J}}$ & $\vec{m}$ & $\stackrel{\text { I }}{\text { ¿ }}$ & $\tilde{n}$ & $\approx$ & $\hat{\imath}$ & $\vec{\infty}$ & $=$ & $\bar{\sigma}$ & $\bar{\sigma}$ & 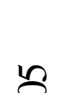 & \\
\hline 武 & $\sim s$ & 范 & ळे & 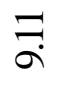 & চ઼ & $\stackrel{E}{i}$ & $\ddot{\theta}$ & 호 & $\underset{i}{8}$ & 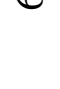 & & $\mathrm{er}$ & 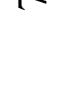 & 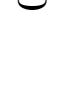 & 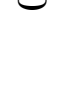 & & \\
\hline 节 & 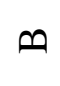 & 苑 & กิ & $r$ & $\stackrel{\text { fo }}{r}$ & m. & $\stackrel{\text { }}{\text { nి }}$ & $\underset{\text { đ̦ }}{\mathbb{J}}$ & $\underset{i}{\text { i }}$ & & & & & & & & \\
\hline 这 & 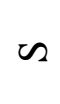 & 血 & ঔ & $\frac{d}{\sigma}$ & $\hat{\sigma}$ & $\stackrel{\infty}{-}$ & i & ه্. & 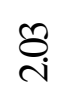 & i & i & $\ddot{n}$ & i & 0 & 0 & : & 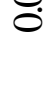 \\
\hline$\stackrel{\Xi}{0}$ & $\varphi$ & 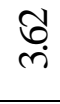 & $\begin{array}{l}n \\
n \\
m\end{array}$ & $\underset{m}{\forall}$ & $\frac{n}{n}$ & ลิ & $\underset{\text { ¿ }}{\text { i }}$ & ठِ & $\stackrel{ \pm}{i}$ & N & $N$ & $\stackrel{\infty}{n}$ & $\stackrel{\infty}{n}$ & ?อ. & ?อ. & ? & ?. \\
\hline$i$ & $\sim s$ & 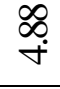 & Sิ & $\stackrel{\text { จุ }}{+}$ & 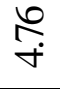 & n & $\stackrel{\infty}{-}$ & กุ & $\stackrel{9}{3}$ & & & & & & & & \\
\hline$\frac{\vec{z}}{3}$ & $\varphi$ & $\stackrel{\delta}{\theta}$ & $\ddot{0}$ & $\stackrel{\beth}{\Xi}$ & $\stackrel{\infty}{=}$ & 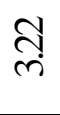 & $\overline{7}$ & nิ & ळे & オ & f & 8 & f & $\bar{\sigma}$ & $\bar{\sigma}$ & $\bar{\sigma}$ & '8 \\
\hline ๘ & $\sim \Omega$ & $\stackrel{f}{ \pm}$ & $\stackrel{\text { f }}{ \pm}$ & $\begin{array}{l}80 \\
\dot{I}\end{array}$ & $\Xi$ & 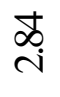 & $\stackrel{+}{m}$ & ஜे & $\stackrel{f}{9}$ & & & & & & & & \\
\hline 尝 & $\varphi$ & $\underset{I}{\stackrel{f}{ \pm}}$ & $\begin{array}{l}m \\
m \\
m\end{array}$ & $\begin{array}{l}8 \\
\dot{\Xi}\end{array}$ & $\begin{array}{l}8 \\
\qquad \\
n\end{array}$ & $\frac{\pi}{n}$ & $\underset{+}{+}$ & F & $\stackrel{\infty}{\infty}$ & $\bar{n}$ & 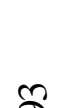 & $\infty$ & & $\bar{z}$ & $\bar{F}$ & & \\
\hline Z & $\sim s$ & के. & $\underset{⿱ 亠 乂}{\Delta}$ & $\begin{array}{l}\infty \\
\stackrel{m}{a}\end{array}$ & 홍 & હ) & F & $\stackrel{\infty}{\forall}$ & $\begin{array}{l}\infty \\
\infty \\
\dot{\sim}\end{array}$ & $\pi$ & 0 & $n$ & & 0 & 0 & 0 & 0 \\
\hline ठัँ & 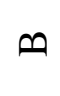 & $\underset{\dot{\sigma}}{\vec{\rho}}$ & $\stackrel{\infty}{\stackrel{\infty}{m}}$ & ñ & $\begin{array}{l}\text { के } \\
\dot{n}\end{array}$ & $\stackrel{m}{n}$ & $N$ & $\stackrel{\nearrow}{\leftrightarrows}$ & $\widehat{ત}$ & 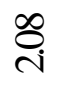 & $\bar{r}$ & $\underset{\text { 오 }}{\text { in }}$ & $\hat{n}$ & $\stackrel{2}{0}$ & $\stackrel{2}{0}$ & ำ & 룽 \\
\hline
\end{tabular}




\begin{tabular}{|c|c|c|c|c|c|c|c|c|c|c|c|c|c|c|c|c|c|}
\hline & $\Omega$ & $\underset{+}{\stackrel{+}{+}}$ & $\underset{⿱ 亠}{\stackrel{\infty}{+}}$ & $\stackrel{\vec{n}}{\forall}$ & $\sqrt[n]{7}$ & $\cong$ & 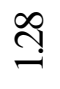 & 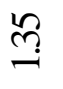 & તุ & & & & & & & & \\
\hline \multirow{2}{*}{ 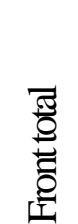 } & 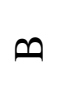 & $\stackrel{\hat{\rho}}{\stackrel{2}{\rho}}$ & $\begin{array}{l}\text { हे } \\
\infty 0\end{array}$ & $\frac{m}{\pi}$ & $\stackrel{\overbrace{}}{\stackrel{n}{N}}$ & $\underset{0}{\stackrel{0}{0}}$ & ชి & $\stackrel{n}{r}$ & $\overline{\widehat{\sigma}}$ & \multirow{2}{*}{$\begin{array}{l}\sqrt[n]{7} \\
\stackrel{d}{2}\end{array}$} & \multirow{2}{*}{ ñ? } & \multirow{2}{*}{$\begin{array}{l}\text { 苍 } \\
\text { ते }\end{array}$} & \multirow{2}{*}{$\begin{array}{l}\infty \\
\stackrel{0}{0} \\
\stackrel{0}{0}\end{array}$} & \multirow{2}{*}{$\bar{\sigma}$} & \multirow{2}{*}{$\bar{\sigma}$} & \multirow{2}{*}{$\bar{\sigma}$} & \multirow{2}{*}{$\bar{\delta}$} \\
\hline & $\Omega$ & ฉू & 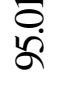 & ลุ & $\begin{array}{l}\bar{\sigma} \\
\dot{\alpha}\end{array}$ & $\underset{\infty}{+}$ & $\underset{\sim}{\sigma}$ & $\begin{array}{l}\infty \\
\infty \\
\infty\end{array}$ & $\overbrace{\infty}^{2}$ & & & & & & & & \\
\hline
\end{tabular}

Table [3] and figures (12-15) show the following:

1. The value of "T" for sizes (S, M, L, and XL) are range between "5.96 to 8.52" neckline which is a statistically significant value at the level "0.01" for "Suggested method", where the average score for method "B" range between "10 to "10.78", while the average score for " Suggested method " range between "13.78 to $14.37 "$.

2. The value of "T" for sizes (S, M, L, and XL) are range between "2.71 to 5.09" Bust line which is a statistically significant value at the level "0.01 to 0.5 " for " Suggested method", where the average score for method "B" range between "6.24 to 7.55", while the average score for " Suggested method " range between "9.12 to $9.92 "$.

3. The value of "T" for sizes (S, M, L, and XL) are range between "2.22 to 2.51" waistline which is a statistically significant value at the level " 0.5 " for " Suggested method", where the average score for method "B" range between "7 to 7.89", while the average score for " Suggested method " range between "9.46 to $9.75^{\prime \prime}$.

4. The value of "T" for sizes (S, M, L, and XL) are range between "2.81 to 7.11" hip line which is a statistically significant value at the level "0.01 to 0.5 " for " Suggested method", where the average score for method "B" range between "6.83 to 7.03", while the average score for " Suggested method " range between "9.11 to $9.89 "$.

5. The value of "T" for sizes (S, M, L, and XL) are range between "2.02 to 5.44" center front line which are statistically significant value at the level "0.01 to 0.5" for " Suggested method", where the average score for method "B" range between "7 to 7.52", while the average score for " Suggested method " range between "9.44 to 9.84 ".

6. The value of "T" for sizes (S, M, L, and XL) are range between "2 to 2.58" sideline which are statistically significant value at the level " 0.5 " for " 
Suggested method", where the average score for method "B" range between "3.15 to 3.62", while the average score for " Suggested method " range between "4.25 to $4.97 "$ "

7. The value of "T" for sizes (S, M, L, and XL) are range between "2.40 to 6.03" shoulder line which is a statistically significant value at the level "0.01 to 0.5 " for " Suggested method", where the average score for method "B" range between "10.1 to 11.38", while the average score for " Suggested method " range between "14 to $14.69 "$ ".

8. The value of "T" for sizes (S, M, L, and XL) are range between "6 to 7.61" armpit which is a statistically significant value at the level "0.01" for " Suggested method", where the average score for method "B" range between "13.36 to 15.03", while the average score for " Suggested method " range between "18.74 to 19.38 ".

9. The value of "T" for sizes (S, M, L, and XL) are range between "2.08 to 2.40" Overall appearance which is a statistically significant value at the level " 0.5 " for " Suggested method", where the average score for method "B" range between "3.52 to 3.84", while the average score for " Suggested method " range between "4.38 to $4.74 "$ ".

10. The value of "T" for sizes (S, M, L, and XL) are range between "19.88 to 24.57" total front which is a statistically significant value at the level "0.01" for " Suggested method", where the average score for method "B" range between "68.59 to 72.35", while the average score for " Suggested method " range between "94.91 to 95.78 ".

The results of the statistical analysis showed the distinction of the suggested modified to the Borgo method in controlling the overall appearance of the front in terms of the neck line, waistline, hip line, center front line, sideline, shoulder, the armpit of all sizes.

\subsection{The second assumption}

There are statistically significant differences between the averages of the specialists' opinions of the two methods at the back of the measurements used S, M, L, and XL". 


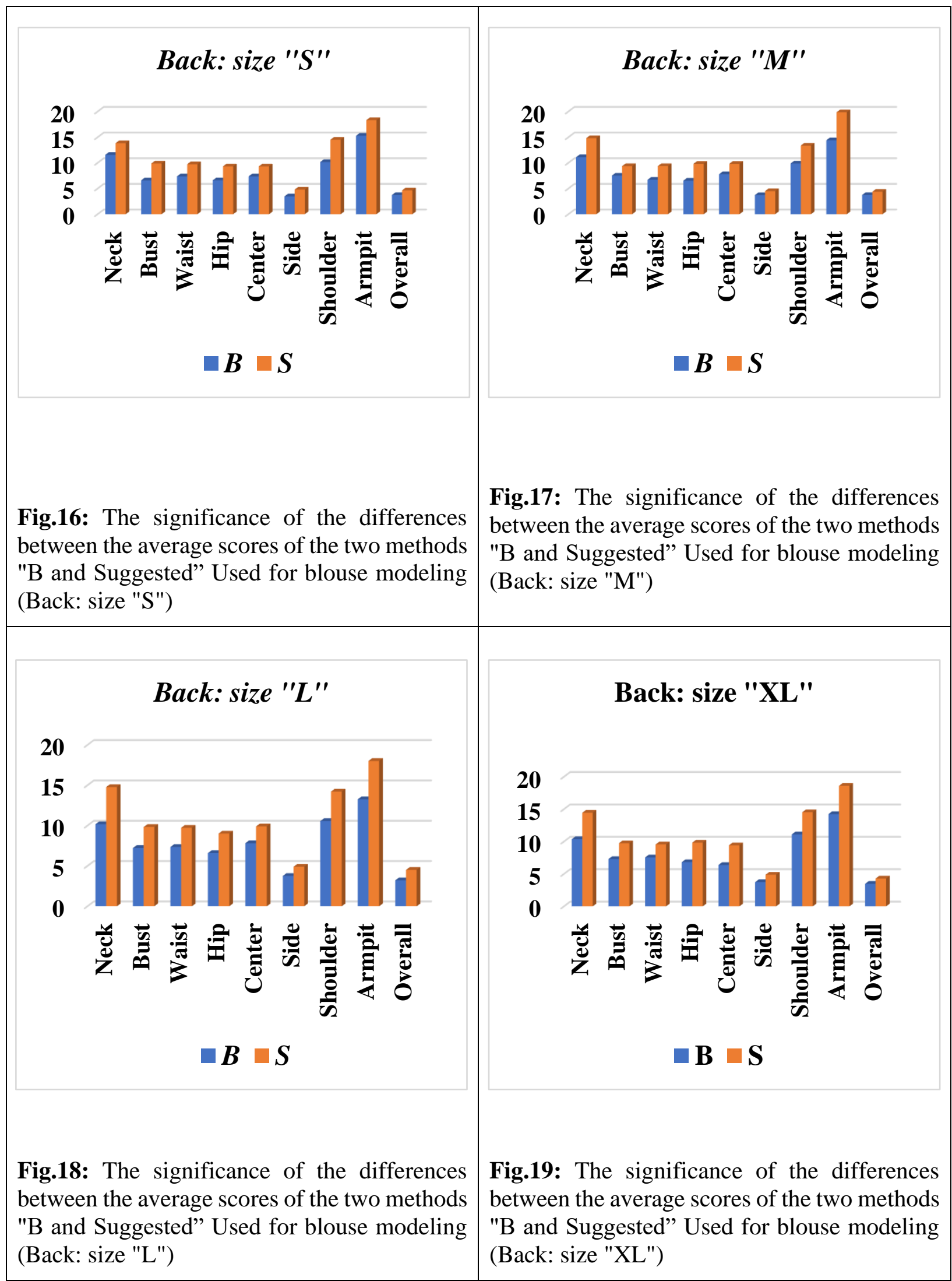


Table [4]: The differences between the averages of the specialists 'opinions of the two methods in the back for the measurements used S, M, L, and XL".

\begin{tabular}{|c|c|c|c|c|c|c|c|c|c|c|c|c|c|c|c|c|c|}
\hline \multicolumn{2}{|c|}{ Back } & \multicolumn{4}{|c|}{ Mean } & \multicolumn{4}{|c|}{ Std. Deviation } & \multicolumn{4}{|c|}{ T-test } & \multicolumn{4}{|c|}{ Significant } \\
\hline \multicolumn{2}{|c|}{$\frac{\stackrel{N}{N}}{\tilde{w}}$} & $n$ & $\Sigma$ & -1 & $\bar{x}$ & $\sim s$ & $\Sigma$ & 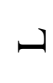 & $\bar{x}$ & as & $\Sigma$ & - & $\vec{x}$ & 佂 & $\Sigma$ & - & $\bar{x}$ \\
\hline & $\infty$ & $\stackrel{\text { ?ִ }}{=}$ & $\begin{array}{l}\exists \\
=\end{array}$ & $\stackrel{-}{=}$ & $\stackrel{\hat{n}}{0}$ & $\hat{\overbrace{}}$ & 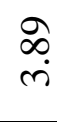 & $\stackrel{n}{n}$ & $\underset{r}{\tilde{r}}$ & \multirow{2}{*}{$\begin{array}{l}0 \\
\hat{i} \\
i\end{array}$} & \multirow[t]{2}{*}{ की } & \multirow{2}{*}{ 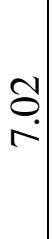 } & \multirow{2}{*}{ mit. } & \multirow{2}{*}{$\stackrel{2}{0}$} & \multirow{2}{*}{$\stackrel{\overline{0}}{\circ}$} & \multirow{2}{*}{ ¿.: } & \multirow{2}{*}{$\overline{0}$} \\
\hline $\begin{array}{l}\frac{y}{u} \\
\ddot{z}\end{array}$ & s & $\begin{array}{l}\dot{\Delta} \\
\dot{0} \\
-\end{array}$ & $\begin{array}{l}0 \\
\dot{J} \\
\dot{J}\end{array}$ & $\begin{array}{l}\stackrel{\infty}{\stackrel{ \pm}{ \pm}} \\
\end{array}$ & $\begin{array}{l}\stackrel{?}{+} \\
\stackrel{+}{ \pm}\end{array}$ & $\vec{m}$ & $\stackrel{\overbrace{}}{\leftrightarrow}$ & $\underset{\oplus}{\stackrel{+}{\sigma}}$ & $\stackrel{n}{n}$ & & & & & & & & \\
\hline \multirow{2}{*}{ 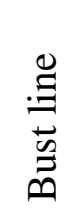 } & $\infty$ & ڤึ. & $\vec{n}$ & $\stackrel{\overbrace{}}{\sim}$ & $\stackrel{m}{r}$ & $\begin{array}{l}\infty \\
\infty \\
i\end{array}$ & $\underset{\mathrm{C}}{\stackrel{0}{\mathrm{i}}}$ & $\stackrel{\overbrace{}}{\mathrm{i}}$ & $\begin{array}{l}\vec{\infty} \\
i\end{array}$ & \multirow{2}{*}{$\stackrel{n}{\square}$} & \multirow{2}{*}{$\begin{array}{l}0 \\
i\end{array}$} & \multirow{2}{*}{$\begin{array}{l}\hat{\sigma} \\
i \\
\text { in }\end{array}$} & \multirow{2}{*}{$\begin{array}{l}\bar{\infty} \\
\mathbf{i}\end{array}$} & \multirow{2}{*}{$\stackrel{\overrightarrow{0}}{0}$} & \multirow{2}{*}{$\stackrel{2}{0}$} & \multirow{2}{*}{2} & \\
\hline & es & $\begin{array}{l}\infty \\
\infty \\
\infty\end{array}$ & $\begin{array}{l}0 \\
? \\
a\end{array}$ & $\begin{array}{l}\infty \\
\sigma \\
\sigma\end{array}$ & $\stackrel{ \pm}{\stackrel{\Delta}{\sigma}}$ & $\underset{i}{F}$ & N & 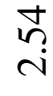 & $\underset{i}{\stackrel{J}{*}}$ & & & & & & & & \\
\hline \multirow{2}{*}{ 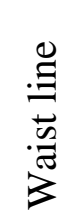 } & $\infty$ & $\stackrel{0}{\sim}$ & $\overrightarrow{6}$ & $\stackrel{\overbrace{}}{r}$ & $\stackrel{n}{n}$ & $\underset{\oplus}{\stackrel{D}{.}}$ & $\stackrel{\text { on }}{i}$ & $\underset{i}{\Delta}$ & $\stackrel{\hat{m}}{.}$ & \multirow{2}{*}{$\underset{\text { f }}{\text { f }}$} & \multirow{2}{*}{$\stackrel{9}{\overrightarrow{+}}$} & \multirow{2}{*}{$\begin{array}{l}\stackrel{?}{f} \\
i\end{array}$} & \multirow{2}{*}{$\begin{array}{l}n \\
i \\
i\end{array}$} & \multirow{2}{*}{$\stackrel{2}{2}$} & \multirow{2}{*}{$\stackrel{\square}{0}$} & \multirow{2}{*}{ ? } & \\
\hline & es & $\stackrel{m}{a}$ & 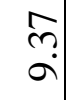 & $\stackrel{\curvearrowright}{\sigma}$ & $\begin{array}{l}\stackrel{n}{n} \\
\text { an }\end{array}$ & $\begin{array}{l}\delta \\
\text { i }\end{array}$ & $\stackrel{\text { ?f }}{\mathrm{i}}$ & $\stackrel{\infty}{\stackrel{-}{-}}$ & $\stackrel{\sim}{\sim}$ & & & & & & & & \\
\hline \multirow{2}{*}{ 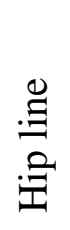 } & $\infty$ & $\vec{\sigma}$ & nู & గึ? & $\stackrel{\widetilde{0}}{0}$ & $\begin{array}{l}\tilde{\sigma} \\
\text { in }\end{array}$ & $\hat{n}$ & $\underset{\leftrightarrow}{\stackrel{\leftrightarrow}{\circ}}$ & $\stackrel{\mathrm{T}}{\mathrm{i}}$ & \multirow{2}{*}{$\stackrel{m}{n}$} & $\hat{n}$ & & $=$ & $\bar{z}$ & $=$ & & \\
\hline & us & సి. & $\begin{array}{l}\hat{N} \\
0 \\
0\end{array}$ & $\stackrel{0}{\circ}$ & $\begin{array}{l}+ \\
\stackrel{+}{0}\end{array}$ & $\begin{array}{l}\text { ô } \\
\text { i }\end{array}$ & $\stackrel{+}{\text { i }}$ & $\underset{\vec{i}}{\overline{\mathrm{C}}}$ & $\begin{array}{l}\mathbb{d} \\
\text { i }\end{array}$ & & & & & & & & \\
\hline$\stackrel{\overrightarrow{0}}{0}$ & $\infty$ & 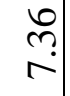 & $\stackrel{2}{i}$ & $\underset{\infty}{\sim}$ & ले & $\underset{\dot{r}}{0}$ & $\stackrel{\mathcal{N}}{m}$ & $\underset{\sim}{\sigma}$ & $\underset{i}{\stackrel{J}{i}}$ & $m$ & 0 & $m$ & & & & & \\
\hline Uే & $\sim$ & $\vec{a}$ & $\begin{array}{c}\sigma \\
0 \\
\sigma\end{array}$ & $\dot{a}$ & $\stackrel{?}{\stackrel{9}{\sigma}}$ & $\stackrel{?}{\stackrel{f}{-}}$ & 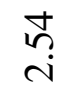 & $\stackrel{n}{i}$ & $\tilde{n}$ & i & i & $i$ & $\sim$ & 0 & 0 & 0 & \\
\hline & $\infty$ & $\stackrel{+}{\dot{f}}$ & $\vec{r}$ & $\stackrel{\bullet}{\stackrel{2}{r}}$ & $\stackrel{+}{\stackrel{+}{r}}$ & $\begin{array}{l}\hat{\sigma} \\
\hat{i}\end{array}$ & $\overrightarrow{\mathrm{N}}$ & $\stackrel{n}{n}$ & $\stackrel{n}{6}$ & & & & & & & & \\
\hline$\frac{\overline{8}}{\bar{\Delta}}$ & es & $\stackrel{2}{+}$ & 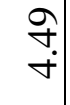 & $\stackrel{\leftrightarrow}{+}$ & $\stackrel{\leftrightarrow}{\stackrel{+}{+}}$ & $\stackrel{0}{\longrightarrow}$ & $\stackrel{\sigma}{\sigma}$ & $\stackrel{n}{n}$ & $\stackrel{\infty}{\infty}$ & & $N$ & $\sim$ & i & 0 & 0 & o & \\
\hline 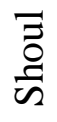 & $\infty$ & $\begin{array}{l}0 \\
0 \\
0\end{array}$ & $\begin{array}{l}\infty \\
\infty \\
\infty \\
\infty\end{array}$ & $\begin{array}{l}0 \\
\stackrel{2}{0} \\
\stackrel{0}{0}\end{array}$ & $\exists$ & 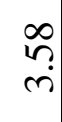 & $\stackrel{\bullet}{\stackrel{8}{r}}$ & $\begin{array}{l}\stackrel{2}{o} \\
\dot{f}\end{array}$ & $\stackrel{g}{\stackrel{q}{r}}$ & $\stackrel{\sim}{\tilde{\sigma}}$ & 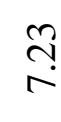 & $\underset{0}{\mathbb{S}}$ & $\begin{array}{l}n \\
\\
i\end{array}$ & $\stackrel{0}{0}$ & $\overline{0}$ & $\stackrel{0}{0}$ & $\bar{c}$ \\
\hline
\end{tabular}




\begin{tabular}{|c|c|c|c|c|c|c|c|c|c|c|c|c|c|c|c|c|c|}
\hline & $\Omega$ & $\begin{array}{l}N \\
\pm \\
\pm\end{array}$ & $\begin{array}{l}\hat{n} \\
\tilde{n}\end{array}$ & $\begin{array}{l}\bar{N} \\
\pm\end{array}$ & $\begin{array}{l}n \\
\stackrel{n}{ \pm}\end{array}$ & $\begin{array}{l}\hat{\sigma} \\
\dot{+}\end{array}$ & 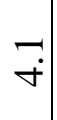 & $\widehat{ָ}$ & $\bar{n}$ & & & & & & & & \\
\hline & $\boldsymbol{n}$ & $\begin{array}{l}\text { ते } \\
\end{array}$ & $\begin{array}{l}\vec{\nabla} \\
\dot{J}\end{array}$ & 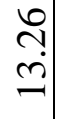 & $\begin{array}{l}\stackrel{ \pm}{ \pm} \\
\stackrel{+}{ \pm}\end{array}$ & $\begin{array}{l}+ \\
n \\
m\end{array}$ & $\stackrel{m}{\underset{\nabla}{f}}$ & $\begin{array}{l}\infty \\
\dot{f}\end{array}$ & $\nabla$ & \multirow{2}{*}{$\begin{array}{l}0 \\
\varnothing \\
r\end{array}$} & \multirow{2}{*}{\begin{tabular}{l}
0 \\
\multirow{2}{*}{} \\
a
\end{tabular}} & \multirow{2}{*}{$\underset{\infty}{二}$} & \multirow{2}{*}{ ọ } & \multirow{2}{*}{ ö } & \multirow{2}{*}{$\stackrel{0}{0}$} & \multirow{2}{*}{$\stackrel{\square}{0}$} & \multirow{2}{*}{ ö } \\
\hline 龸 & $\Omega$ & $\begin{array}{l}m \\
m \\
\infty\end{array}$ & $\begin{array}{l}n \\
\infty \\
a \\
2\end{array}$ & $\begin{array}{l}\overline{0} \\
\infty \\
-1\end{array}$ & $\begin{array}{l}0 \\
\infty \\
\infty\end{array}$ & $\begin{array}{l}0 \\
\text { î } \\
\end{array}$ & $\begin{array}{l}\hat{\infty} \\
\dot{n}\end{array}$ & $\vec{\nabla}$ & $\stackrel{\infty}{\stackrel{\infty}{+}}$ & & & & & & & & \\
\hline \multirow{2}{*}{$\begin{array}{l}\overline{\bar{\pi}} \\
\overline{0} \\
0\end{array}$} & $\boldsymbol{n}$ & $\stackrel{N}{r}$ & $\stackrel{m}{m}$ & 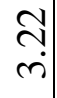 & $\begin{array}{l}\text { gे } \\
\text { r. }\end{array}$ & $\hat{\sigma}$ & $\begin{array}{l}\widehat{d} \\
\dot{i} \\
\end{array}$ & 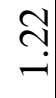 & $\stackrel{\Omega}{-}$ & \multirow{2}{*}{$\begin{array}{l}\vec{\nabla} \\
\stackrel{\sim}{*}\end{array}$} & \multirow{2}{*}{$\begin{array}{l}\text { ণ̦ } \\
\text { ત̇ }\end{array}$} & \multirow{2}{*}{$\begin{array}{l}\text { ㄱ } \\
\text { ㄱ }\end{array}$} & \multirow{2}{*}{$\begin{array}{l}\tilde{n} \\
\tilde{i}\end{array}$} & \multirow{2}{*}{$\stackrel{n}{0}$} & \multirow{2}{*}{$\stackrel{n}{0}$} & \multirow{2}{*}{$\stackrel{n}{0}$} & \multirow{2}{*}{$\stackrel{n}{0}$} \\
\hline & $\Omega$ & $\begin{array}{l}\vec{v} \\
\dot{\nabla}\end{array}$ & $\hat{\nabla}$ & $\bar{r}$ & సे & $\stackrel{3}{=}$ & ?ִ & ఏ & $\stackrel{n}{n}$ & & & & & & & & \\
\hline \multirow{2}{*}{ 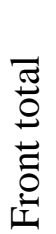 } & $\boldsymbol{n}$ & $\vec{N}$ & $\frac{n}{\pi}$ & ఏి & $\stackrel{0}{-}$ & তె & $\begin{array}{l}0 \\
0 \\
0\end{array}$ & $\underset{0}{8}$ & ฌ) & \multirow{2}{*}{$\begin{array}{l}m \\
\overrightarrow{0}\end{array}$} & \multirow{2}{*}{$\begin{array}{l}\vec{m} \\
\vec{n}\end{array}$} & \multirow{2}{*}{$\begin{array}{l}\stackrel{ \pm}{+} \\
\stackrel{\sim}{+}\end{array}$} & \multirow{2}{*}{$\begin{array}{l}\stackrel{y}{~} \\
\stackrel{\sim}{~}\end{array}$} & \multirow{2}{*}{$\begin{array}{l}0 \\
0\end{array}$} & \multirow{2}{*}{0} & \multirow{2}{*}{$\begin{array}{l}\overrightarrow{0} \\
0\end{array}$} & \multirow{2}{*}{ రం } \\
\hline & $n$ & $\begin{array}{l}\tilde{n} \\
\tilde{\sigma}\end{array}$ & 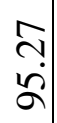 & $\begin{array}{l}0 \\
\infty \\
\dot{+}\end{array}$ & ñ & $\infty$ & $\underset{\infty}{\stackrel{N}{ }}$ & & $\begin{array}{l}0 \\
\text { n? }\end{array}$ & & & & & & & & \\
\hline
\end{tabular}

Table [4] and figures (16-19) show the following:

1. The value of "T" for sizes (S, M, L, and XL) are range between "2.69 to 7.59" neckline which is a statistically significant value at the level "0.01 to 0.05 " for "Suggested method", where the average score for method "B" range between "10.17 to "11.65", while the average score for " Suggested method " range between "13.84 to 14.82".

2. The value of "T" for sizes (S, M, L, and XL) are range between "2.6 to 4.59" Bust line which is a statistically significant value at the level "0.01 to 0.5 " for " Suggested method ", where the average score for method "B" range between "6.59 to 7.51", while the average score for " Suggested method " range between "9.36 to 9.88".

3. The value of "T" for sizes (S, M, L, and XL) are range between "2.22 to 2.51" waistline which is a statistically significant value at the level "0.01 to 0.5 " for " Suggested method ", where the average score for method "B" range between "6.71 to 7.55 ", while the average score for " Suggested method " range between "9.37 to 9.73".

4. The value of "T" for sizes (S, M, L, and XL) are range between "5.33 to 5.63 hip line which are statistically significant value at the level "0.01" for " Suggested method", where the average score for method "B" range between "6.53 to 6.83", while the average score for " Suggested method " range between "9.01 to 9.84". 
5. The value of "T" for sizes (S, M, L, and XL) are range between "2.03 to 7.26" center front line which are statistically significant value at the level "0.01 to 0.5 " for " Suggested method", where the average score for method "B" range between "6.39 to 7.82", while the average score for " Suggested method " range between "9.31 to 9.9".

6. The value of "T" for sizes (S, M, L, and XL) are range between "2.08 to 2.41 sideline which is a statistically significant value at the level "0.5" for " Suggested method", where the average score for method "B" range between "3.47 to 3.76", while the average score for " Suggested method " range between "4.49 to 4.9".

7. The value of "T" for sizes (S, M, L, and XL) are range between "5.25 to 7.23" shoulder line which is a statistically significant value at the level "0.01" for " Suggested method", where the average score for method "B" range between "9.88 to 11.11", while the average score for " Suggested method " range between "13.37 to 14.53".

8. The value of " $\mathrm{T}$ " for sizes (S, M, L, and XL) are range between "7.09 to 9.40" armpit which is a statistically significant value at the level "0.01" for " Suggested method", where the average score for method "B" range between "13.26 to 15.29", while the average score for " Suggested method " range between "18.01 to 19.85".

9. The value of "T" for sizes (S, M, L, and XL) are range between "2.20 to 2.59" Overall appearance which is a statistically significant value at the level " 0.5 " for " Suggested method", where the average score for method "B" range between "3.22 to 3.73", while the average score for " Suggested method " range between "4.29 to 4.64".

10. The value of "T" for sizes (S, M, L, and XL) are range between "20.13 to 24.24" total front which are statistically significant value at the level "0.01" for " Suggested method", where the average score for method "B" range between "69.95 to 72.12", while the average score for " Suggested method " range between "94.53 to 95.32".

The results of the statistical analysis showed the distinction of the suggested modified to the Borgo method in controlling the overall appearance of the back in terms of neckline, waistline, hip line, center front line, sideline, shoulder, the armpit of all sizes.

\subsection{The third assumption:}

There are statistically significant differences between the averages of the opinions of specialists in the two methods of the sleeve of the measurements used S, M, L, and XL". 


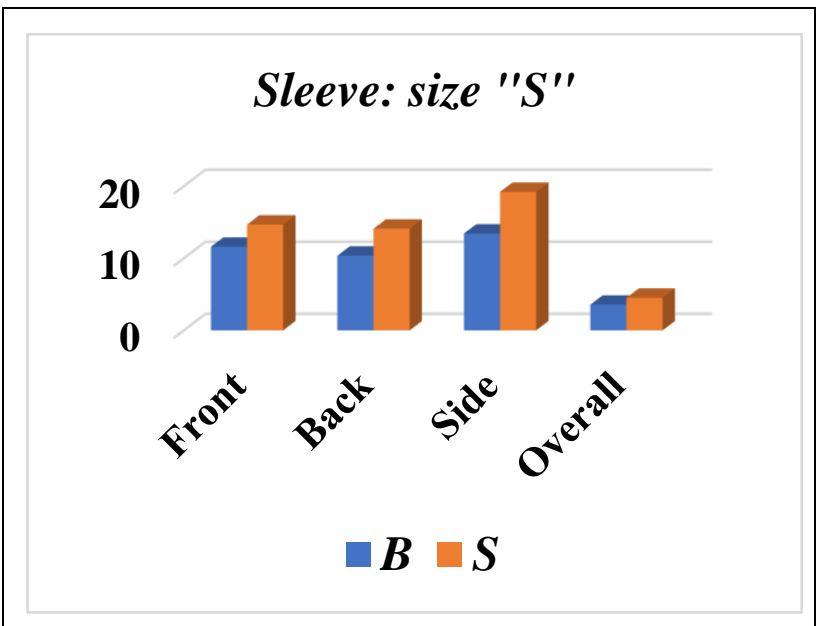

Fig.20: The significance of the differences between the average scores of the two methods "B and Suggested" Used for blouse modeling (Sleeve: size "S")

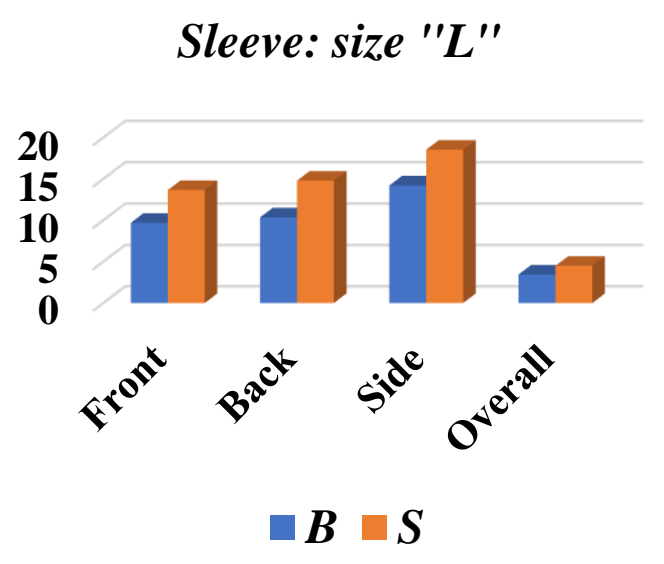

Fig.22: The significance of the differences between the average scores of the two methods "B and Suggested" Used for blouse modeling (Sleeve: size "L")

\section{Sleeve: size "M"}

20
10
0

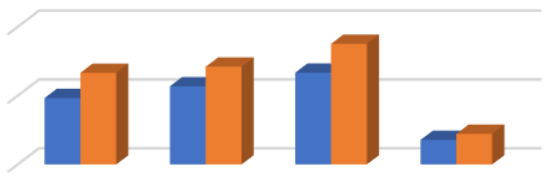<smiles>[CH][CH]</smiles><smiles>[13CH]</smiles><smiles></smiles>

$\boldsymbol{B} \square S$

Fig.21: The significance of the differences between the average scores of the two methods "B and Suggested" Used for blouse modeling (Sleeve: size "M")

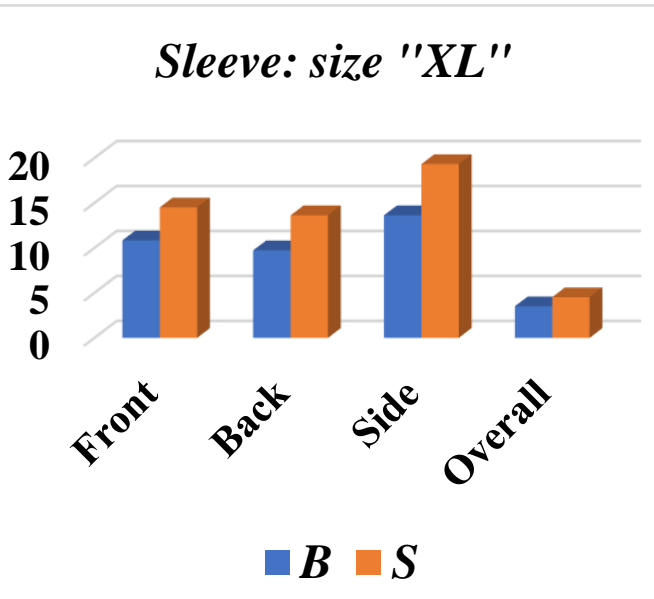

Fig.23: The significance of the differences between the average scores of the two methods "B and Suggested" Used for blouse modeling (Sleeve: size "XL") 
Table [5]: The differences between the averages of the specialists' opinions of the two methods in the sleeve for the measurements used S, M, L, and XL".

\begin{tabular}{|c|c|c|c|c|c|c|c|c|c|c|c|c|c|c|c|c|c|}
\hline \multirow[b]{2}{*}{ 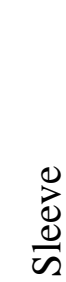 } & & \multicolumn{4}{|c|}{ Mean } & \multicolumn{4}{|c|}{ Std. Deviation } & \multicolumn{4}{|c|}{ T-test } & \multicolumn{4}{|c|}{ Significant } \\
\hline & & s & $\Sigma$ & -1 & $\vec{x}$ & $\Omega$ & $\Sigma$ & -1 & $\bar{x}$ & $n$ & $\Sigma$ & -1 & $\vec{x}$ & $\omega$ & $\Sigma$ & -1 & $\bar{x}$ \\
\hline & $ص$ & $\stackrel{n}{=}$ & $\begin{array}{l}\bullet \\
: \\
\circ\end{array}$ & $\vec{a}$ & $\begin{array}{l}+ \\
\infty \\
0 \\
0\end{array}$ & $\begin{array}{l}\tilde{n} \\
\dot{n}\end{array}$ & 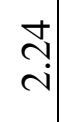 & $\stackrel{n}{n}$ & $\stackrel{\tilde{n}}{n}$ & \multirow{2}{*}{$\stackrel{2}{r}$} & \multirow{2}{*}{ ֶి } & \multirow[t]{2}{*}{ of } & \multirow{2}{*}{$\begin{array}{l}t \\
b \\
b\end{array}$} & \multirow{2}{*}{$\begin{array}{l}0 \\
0 \\
0\end{array}$} & \multirow{2}{*}{ 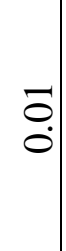 } & \multirow{2}{*}{$\begin{array}{l}-\sigma \\
0\end{array}$} & \multirow{2}{*}{$\stackrel{0}{0}$} \\
\hline 苛 & as & $\begin{array}{l}\hat{\sigma} \\
\dot{I}\end{array}$ & 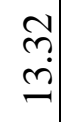 & $\begin{array}{l}0 \\
\dot{0} \\
\dot{0}\end{array}$ & $\begin{array}{l}\vec{n} \\
\dot{ \pm}\end{array}$ & $\begin{array}{l}\stackrel{\partial}{0} \\
\dot{r}\end{array}$ & $\begin{array}{l}0 \\
i\end{array}$ & $\begin{array}{l}n \\
\dot{r} \\
0\end{array}$ & $\begin{array}{l}n \\
\stackrel{n}{n}\end{array}$ & & & & & & & & \\
\hline & 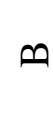 & $\begin{array}{l}0 \\
\\
\varrho\end{array}$ & $\stackrel{n}{\tilde{n}}$ & $\begin{array}{l}0 \\
\\
0\end{array}$ & $\underset{\sigma}{\stackrel{t}{a}}$ & $\stackrel{m}{m}$ & $\stackrel{\hat{0}}{\dot{m}}$ & $\stackrel{n}{\tilde{\sigma}}$ & $\begin{array}{l}\infty \\
\infty \\
i\end{array}$ & \multirow{2}{*}{ An } & \multirow{2}{*}{ o } & \multirow[t]{2}{*}{2} & \multirow{2}{*}{ 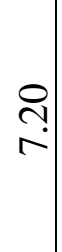 } & \multirow{2}{*}{$\begin{array}{l}\overrightarrow{0} \\
\stackrel{0}{0}\end{array}$} & \multirow{2}{*}{$\begin{array}{l}0 \\
0\end{array}$} & \multirow{2}{*}{$\ddot{0}$} & \\
\hline $\begin{array}{l}\frac{y}{\tilde{E}} \\
\tilde{\mathscr{n}}\end{array}$ & as & J & $\begin{array}{l}\vec{v} \\
\dot{ \pm}\end{array}$ & $\begin{array}{l}\infty \\
\dot{ \pm}\end{array}$ & $\begin{array}{l}\hat{b} \\
\dot{n}\end{array}$ & 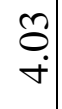 & $\underset{i}{\stackrel{ }{i}}$ & $\begin{array}{l}8 \\
\dot{r}\end{array}$ & 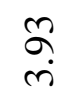 & & & & & & & & \\
\hline & $\boldsymbol{n}$ & $\stackrel{\text { I }}{\stackrel{7}{2}}$ & $\begin{array}{c}m \\
\end{array}$ & $\begin{array}{l}\tilde{I} \\
\dot{\Xi}\end{array}$ & $\begin{array}{l}3 \\
\dot{0} \\
0\end{array}$ & $\begin{array}{l}\overrightarrow{+} \\
\dot{+}\end{array}$ & $\begin{array}{l}\infty \\
\infty \\
\end{array}$ & $\stackrel{\diamond}{\sigma}$ & $\theta$ & \multirow{2}{*}{ శ్రి } & \multirow{2}{*}{$n$} & \multirow{2}{*}{9} & \multirow{2}{*}{$\underset{\infty}{\stackrel{J}{\infty}}$} & \multirow{2}{*}{$\begin{array}{l}\overrightarrow{0} \\
\circ\end{array}$} & \multirow{2}{*}{$\overline{0}$} & \multirow{2}{*}{$\overline{0}$} & \\
\hline$\overline{0}$ & as & $\stackrel{\sim}{2}$ & $\stackrel{n}{\bumpeq}$ & $\begin{array}{l}\vdots \\
\vdots \\
\infty \\
-\infty\end{array}$ & $\stackrel{1}{2}$ & $\stackrel{\overbrace{}}{\leftrightarrow}$ & $\stackrel{\tilde{r}}{\dot{r}}$ & $\begin{array}{l}+ \\
\infty \\
\text { r. }\end{array}$ & $\stackrel{\text { f }}{m}$ & & & & & & & & \\
\hline \multirow{2}{*}{ 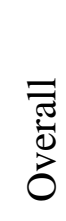 } & $ص$ & $\begin{array}{l}\mathscr{n} \\
m\end{array}$ & $\begin{array}{l}\stackrel{0}{ } \\
\end{array}$ & $\begin{array}{l}n \\
r \\
r\end{array}$ & $\vec{r}$ & $\begin{array}{l}0 \\
: \\
i\end{array}$ & $\Xi$ & $\stackrel{\partial}{-}$ & $\stackrel{8}{-}$ & \multirow{2}{*}{$\widetilde{i}$} & \multirow{2}{*}{ તุ } & \multirow{2}{*}{ 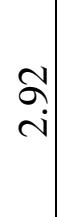 } & \multirow{2}{*}{ 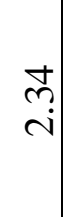 } & \multirow{2}{*}{$\stackrel{2}{0}$} & \multirow{2}{*}{$\begin{array}{l}n \\
0 \\
0\end{array}$} & & \\
\hline & as & $\stackrel{\sim}{\sim}$ & $\begin{array}{l}+ \\
\dot{f}\end{array}$ & $\stackrel{n}{f}$ & $\stackrel{\tilde{r}}{+}$ & $\stackrel{\wp}{\sigma}$ & $\stackrel{\leftrightarrow}{\oplus}$ & $\stackrel{H}{\rightarrow}$ & $\stackrel{\cong}{\rightarrow}$ & & & & & & & & \\
\hline స్ّే & 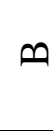 & $\begin{array}{l}m \\
\infty \\
\infty\end{array}$ & 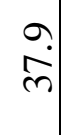 & $\begin{array}{c}\stackrel{n}{0} \\
\hat{n}\end{array}$ & $\stackrel{F}{\stackrel{n}{m}}$ & $\stackrel{\overbrace{}}{\stackrel{+}{+}}$ & 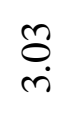 & $\stackrel{\circ}{\stackrel{2}{m}}$ & $\stackrel{\text { : }}{\sim}$ & fo & $\infty$ & $\bar{n}$ & ?̊! & $\bar{\sigma}$ & $\bar{\sigma}$ & $\bar{\sigma}$ & \\
\hline$\frac{\vec{\otimes}}{\tilde{\omega}}$ & $\Omega$ & $\begin{array}{l}\text { aे } \\
\text { in }\end{array}$ & $\begin{array}{c}\hat{q} \\
\dot{q}\end{array}$ & $\overrightarrow{\vec{n}}$ & $\frac{\stackrel{\partial}{a}}{\bar{n}}$ & $\overrightarrow{0}$ & $\underset{\text { S. }}{\tilde{s}}$ & $\hat{n}$ & $\underset{i}{f}$ & & & & & & & & \\
\hline
\end{tabular}

Table [5] and figures (20-23) show the following:

1. The value of "T" for sizes (S, M, L, and XL) are range between "6.23 to 9.40" front which is a statistically significant value at the level "0.01" for method " Suggested method" , 
where the average score for method "B" range between "9.66 to 11.59", while the average score for method " Suggested method " range between "13.32 to 14.67".

2. The value of "T" for sizes (S, M, L, and XL) are range between "5.89 to 8.24" back which is a statistically significant value at the level "0.01" for method " Suggested method" , where the average score for method "B" range between "9.74 to 10.36", while the average score for method " Suggested method " range between "14.1 to 14.8".

3. The value of "T" for sizes (S, M, L, and XL) are range between "6.33 to 8.57 " side which is a statistically significant value at the level "0.01" for method " Suggested method" , where the average score for method "B" range between "13.33 to 14.22", while the average score for method " Suggested method " range between "17.52 to 19.32".

4. The value of "T" for sizes (S, M, L, and XL) are range between "2.2 to 2.92 " overall appearance which is a statistically significant value at the level " 0.05 " for method " Suggested method", where the average score for method "B" range between "3.45 to 3.56", while the average score for method " Suggested method " range between "4.44 to 4.53".

5. The value of "T" for sizes (S, M, L, and XL) are range between "10.85 to 14.56 " sleeve total which is a statistically significant value at the level "0.01" for method " Suggested method", where the average score for method "B" range between "37.71 to 38.93", while the average score for method " Suggested method " range between "49.49 to 52.49".

The results of the statistical analysis showed the distinction of the suggested modified to the Borgo method in controlling the overall appearance of the sleeve in terms of front, back, a sideline of all sizes.

\subsection{The fourth assumption:}

There are statistically significant differences between the averages of the opinions of specialists in the two methods of the total of the measurements used "S, M, L, and XL". 


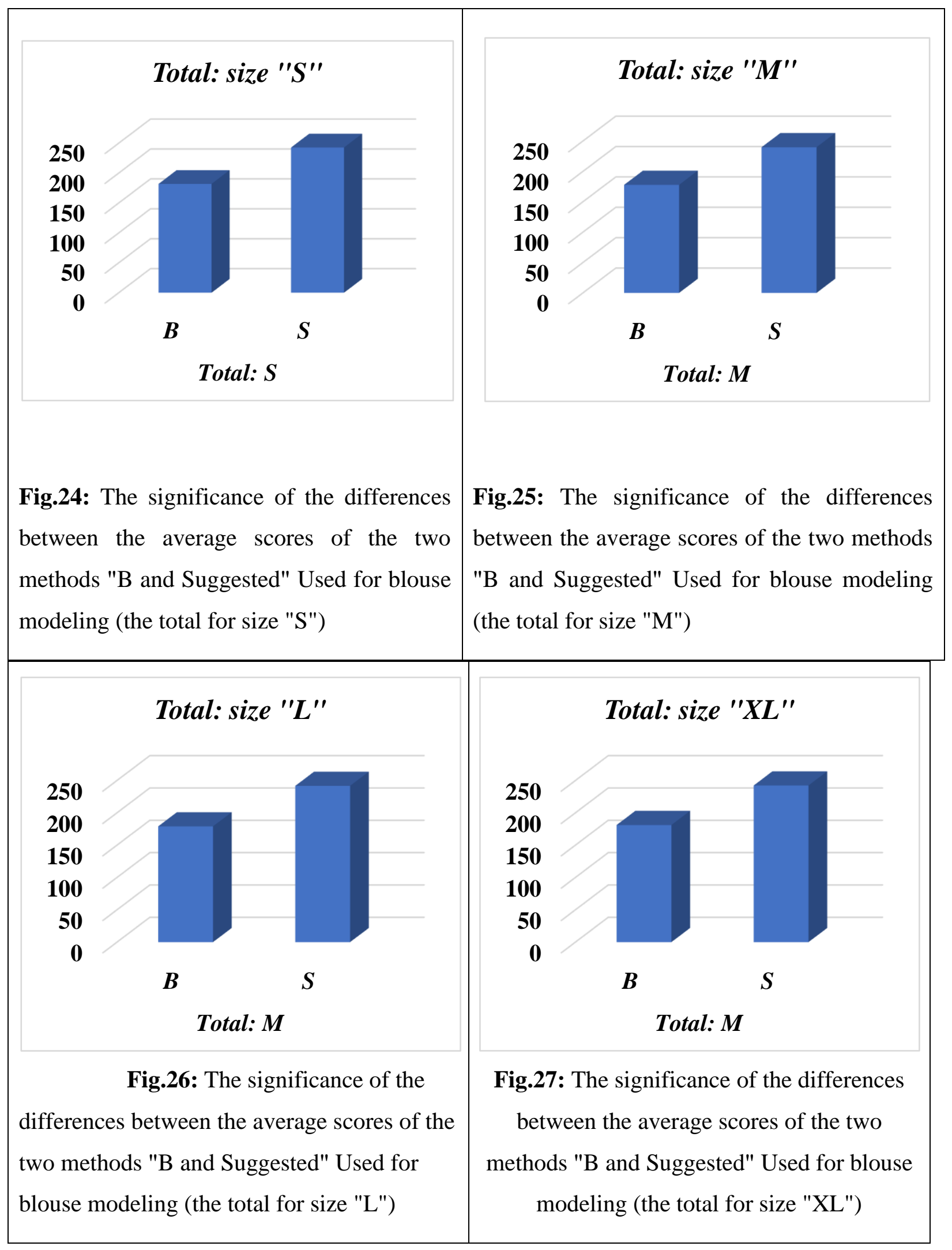


Table [6]: The differences between the averages of the specialists 'opinions of the two methods in the total for the measurements used S, M, L, and XL".

\begin{tabular}{|c|c|c|c|c|c|c|c|c|c|c|c|c|c|c|c|c|}
\hline \multirow{2}{*}{ 氶 } & \multicolumn{4}{|c|}{ Mean } & \multicolumn{4}{|c|}{ Std. Deviation } & \multicolumn{4}{|c|}{ T-test } & \multicolumn{4}{|c|}{ Significant } \\
\hline & $\mathrm{S}$ & M & $\mathrm{L}$ & XL & S & M & $\mathrm{L}$ & $\mathrm{XL}$ & S & M & $\mathrm{L}$ & XL & $\mathrm{S}$ & M & $\mathrm{L}$ & $\mathrm{XL}$ \\
\hline B & 181.82 & 177.88 & 178.98 & 181.08 & 11.21 & 10.15 & 12.03 & 12.21 & 34.20 & 36.42 & 32.26 & 30.67 & 0.01 & 0.01 & 0.01 & 0.01 \\
\hline S & 242.61 & 239.77 & 241.61 & 242.22 & 12.65 & 13.03 & 14.59 & 13.56 & & & & & & & & \\
\hline
\end{tabular}

Table (6) and figures (24-27) show the following:

The value of "T" for sizes (S, M, L, and XL) are range between "30.67 to 36.42" for the total sum, which is a statistically significant value at the level "0.01" for "suggested method", where the average score for method "B" range between "177.88 to 181.82 ", while the average score for " suggested method " range between "239.77 to 242.61".

\section{Discussion:}

There is a statistically significant value at the level (0.01 to 0.05$)$ among the two methods used in the study for the four sizes (S, M, L, and XL) in achieving aspects of the evaluation according to the opinions of the arbitrators of the methods of implementation (Borgo method and new suggested method) to constructing the block pattern without dart for women. The results showed that the sum of the averages of the judges for the models implemented in the new suggested method is better in achieving aspects evaluation as a whole followed by the method of Borgo (B), and we conclude from this that the method of Borgo (B) is not suitable for the bodies of Egyptian women and that the (new suggested) method is the best way to achieve the evaluation aspects in terms of (neckline, bust line, waistline, hip line, center front line, sideline, also for shoulder, armpit and overall Appearance), followed by the method of Borgo (B).

\section{Conclusion:}

The necessity of giving more attention to the study of Egyptian women's body measurements because of their clear impact on controlling the fitting of the block pattern and 
consequently affecting the shape of the final product. So, it is of great importance to study the pattern industry as one of the main factors for the quality of the final product.

This study presented a method of easy fitting block pattern depended on the Egyptian women's body measurements and the basic ease to reach block patterns suitable for Egyptian women's body. And the suggested method can be constructing from the following measurements and steps:

\subsection{The bodice block of the suggested method:}

The measurements required to draft the suggested bodice block pattern are bust circumference, neck circumference, back width measurement, nape to waist length, waist to hip length, shoulder length, waist circumference, and hip circumference.

\section{A. Step one:}

Form a rectangle, down from 0. See fig. (26)

0-1 Nape to waist measurement $+1.7 \mathrm{~cm}$ [mark this line the CB line].

0-2 Half bust measurement $+6 \mathrm{~cm}$ [6 to $10 \mathrm{~cm}$ ] across down to 3 [mark this line the CF line]; square across.

0-4 Back neck depth $1.7 \mathrm{~cm}$ for all sizes.

4-5 Half nape to waist measurement $+2.5 \mathrm{~cm}$; across to 6 . (point 7 is midway between 5 and 6 across down).

1-8 waist to hip measurement; across to 9.

\section{B. Step two: Back}

4-10 Back slope shoulder, $3.5 \mathrm{~cm}$ (square halfway across the block)

0-11 One fifth neck measurement $+0.5 \mathrm{~cm}$ (draw the back-neck curve)

11-12 Shoulder length measurement $+1 \mathrm{~cm}$

5-13 Halfback width $+1.5 \mathrm{~cm}$. (square up to 14 , point 15 is midway between 13 and 14 )

[ Draw the back-armhole curve. outside $0.75 \mathrm{~cm}$ at 15 ]. 


\section{Step three: Front}

2-16 One fifth neck measurement $+0.5 \mathrm{~cm}$.

2-17 One fifth neck measurement $+1.2 \mathrm{~cm}$ [draw front neck curve].

2-18 Front slope shoulder $6.7 \mathrm{~cm}$, (square halfway across the block).

6-19 Half back width $+0.5 \mathrm{~cm}$ (square up to 20, point 21 is midway between 19 and 20)

16-22 Shoulder length measurement $+1 \mathrm{~cm}$.

[ Draw the back-armhole curve. outside $1.2 \mathrm{~cm}$ at 21 ].

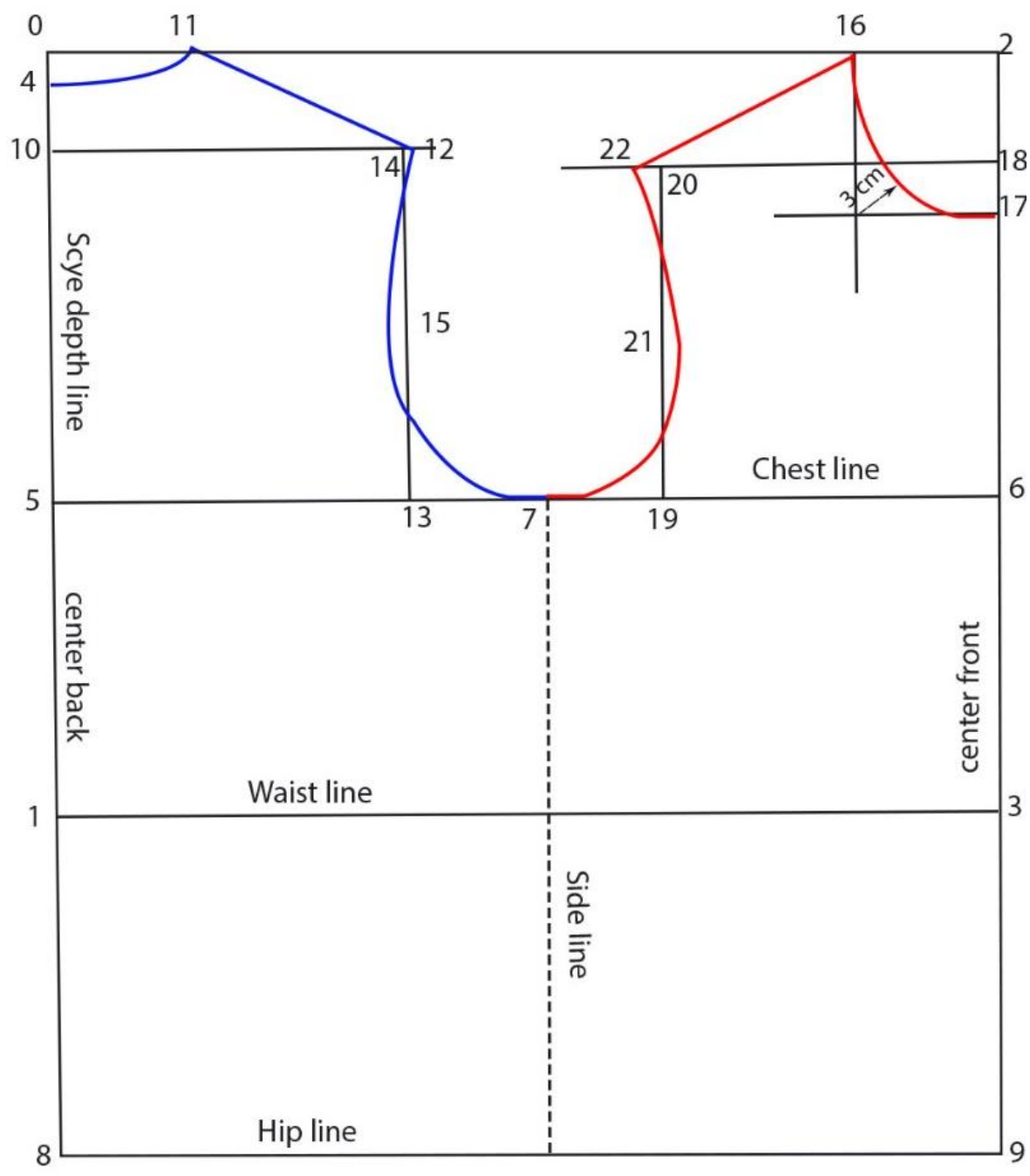

Fig.26: The suggested block pattern. 


\subsection{The Sleeve block of the suggested method:}

The measurements required to draft the suggested sleeve block pattern are armhole measurement (taken accurately upon the basic block of armhole circumference), sleeve length, and wrist circumference. The draft of the suggested sleeve block pattern can construct by. Form a rectangle, down from 0 See fig. (27): 0-1 Fashion sleeve length [mark this line the center line], 0-2 One quarter armhole measurement $+1 \mathrm{~cm}$; square across, $0-3$ Half armhole measurement $-0.5 \mathrm{~cm}$; square down to 4; (divide this line to 4 sections), Raise the curve $1.5 \mathrm{~cm}$ at 7 , and hollow the curve $1 \mathrm{~cm}$ at 9, 0-5 Half armhole measurement $-0.5 \mathrm{~cm}$; square down to 6; (divide this line into 4 sections). Raise the curve $1 \mathrm{~cm}$ at 10 , and hollow the curve $0.75 \mathrm{~cm}$ at 12 .

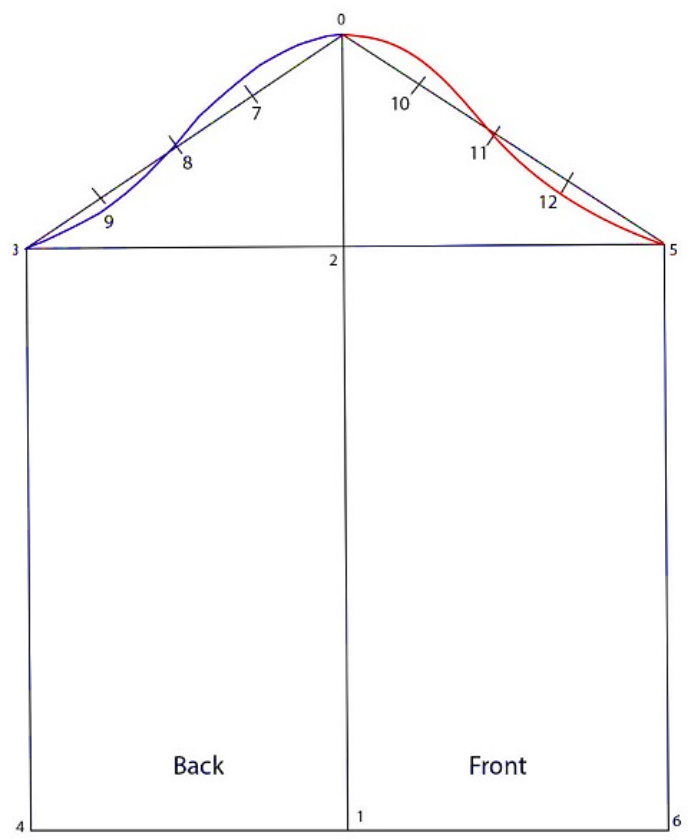

Fig.27: The suggested sleeve block pattern. 


\section{Recommendations:}

1. Interest in making similar researches that are concerned with modifying the pattern used in the industry according to the requirements of the needs of the labor market.

2. Benefiting from experiments and scientific research and exchanging experiences with ready-made garment factories to reach the high required quality level.

\section{Appendix 1}

Questionnaire sheet for the accomplishment of comparison between two methods for making block pattern easy fitting.

Name:

college:

Position:

Method ( )

Sample No. ( )

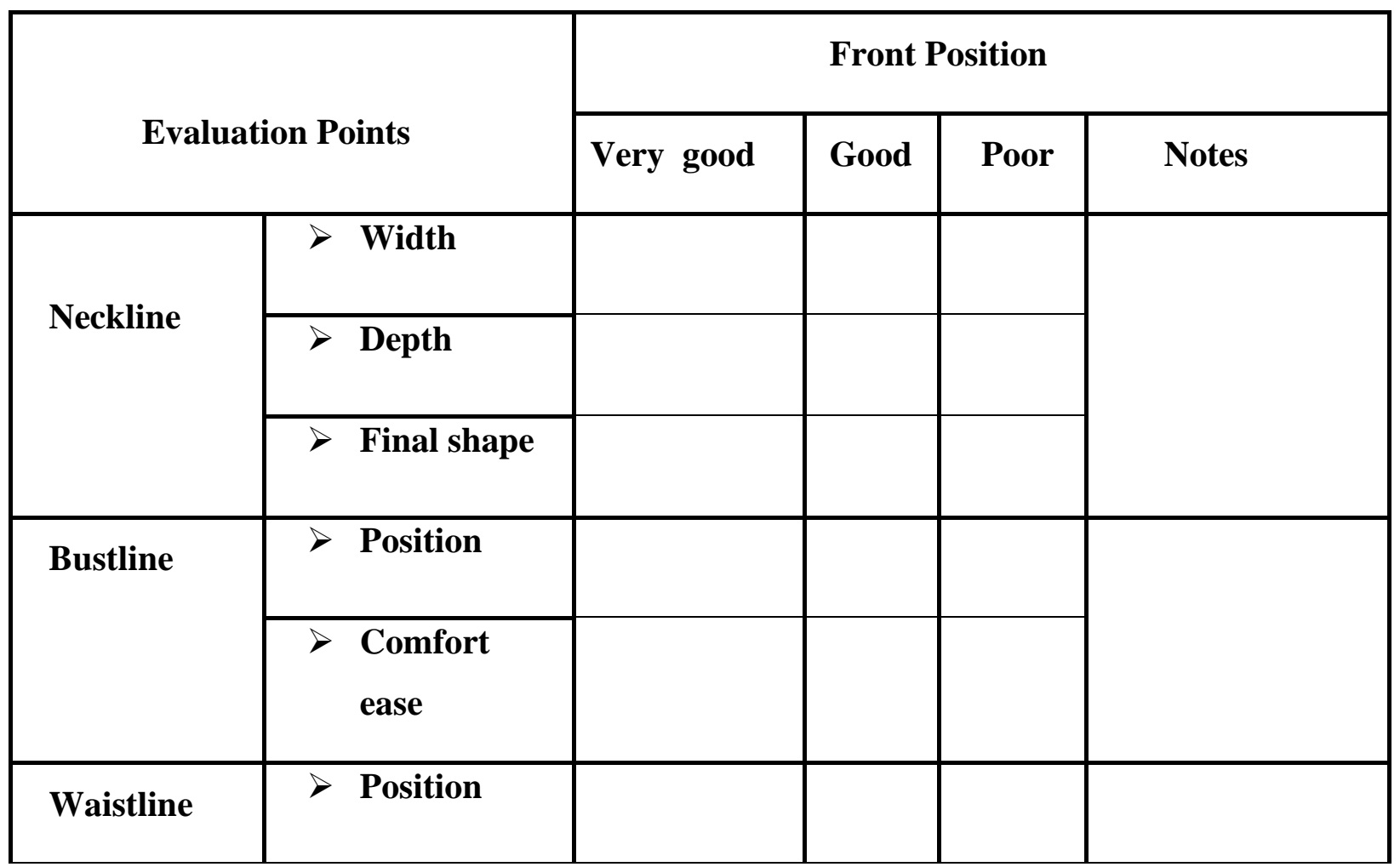




\begin{tabular}{|c|c|c|c|c|c|}
\hline \multirow{2}{*}{\multicolumn{2}{|c|}{ Evaluation Points }} & \multicolumn{4}{|c|}{ Front Position } \\
\hline & & \multirow{2}{*}{ Very good } & \multirow[t]{2}{*}{ Good } & \multirow[t]{2}{*}{ Poor } & \multirow{2}{*}{ Notes } \\
\hline & $\begin{array}{l}\text { Comfort } \\
\text { ease }\end{array}$ & & & & \\
\hline \multirow{2}{*}{ Hipline } & $>$ Position & & & & \\
\hline & $\begin{aligned} & \text { Comfort } \\
& \text { ease }\end{aligned}$ & & & & \\
\hline \multirow{2}{*}{$\begin{array}{c}\text { Center front } \\
\text { line }\end{array}$} & $>$ Position & & & & \\
\hline & $>$ straight & & & & \\
\hline Sideline & $>$ Position & & & & \\
\hline \multirow{3}{*}{ Shoulder } & $>$ Length & & & & \\
\hline & $>$ Slope & & & & \\
\hline & $>$ Position & & & & \\
\hline \multirow{4}{*}{ Armpit } & $>$ Depth & & & & \\
\hline & $>$ Width & & & & \\
\hline & $>$ Position & & & & \\
\hline & $>$ Total fit & & & & \\
\hline \multicolumn{2}{|c|}{ Overall Appearance } & & & & \\
\hline
\end{tabular}




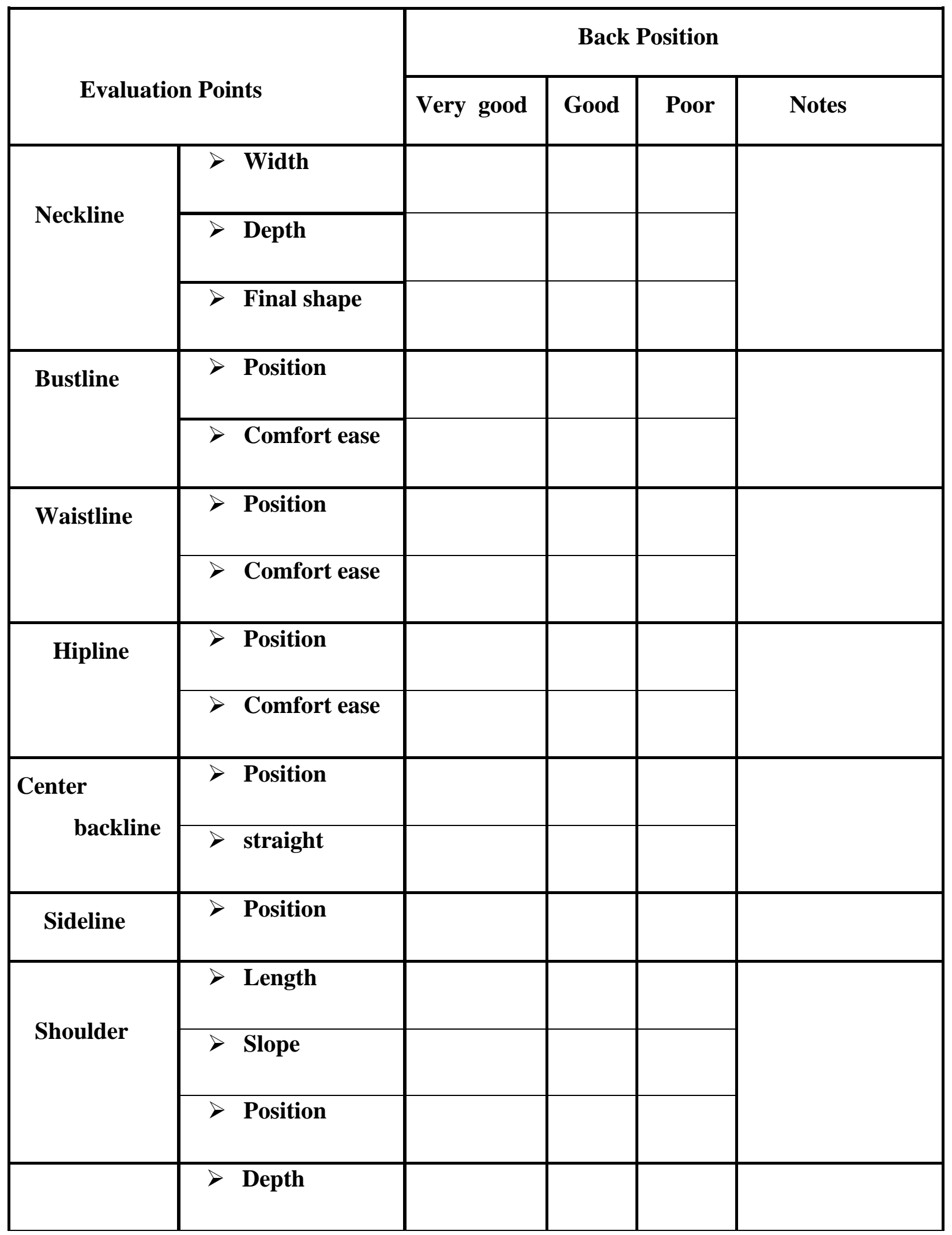




\begin{tabular}{|c|c|l|l|l|l|}
\hline \multirow{2}{*}{ Evaluation Points } & \multicolumn{4}{|c|}{ Back Position } \\
\cline { 2 - 6 } & Very good & Good & Poor & Notes \\
\cline { 2 - 6 } & $>$ Width & & & & \\
\cline { 2 - 6 } & $>$ Position & & & & \\
\cline { 2 - 6 } & $>$ Total Fit & & & & \\
\hline \multicolumn{2}{|c|}{ Overall Appearance } & & & & \\
& & & & & \\
\hline
\end{tabular}

\begin{tabular}{|c|c|c|c|c|c|}
\hline \multirow{2}{*}{\multicolumn{2}{|c|}{ Evaluation Points }} & \multicolumn{4}{|c|}{ Sleeve } \\
\hline & & Very good & Good & Poor & Notes \\
\hline \multirow{3}{*}{ Front } & $>$ armhole & & & & \\
\hline & $>$ Upper arm & & & & \\
\hline & $>$ Appearance & & & & \\
\hline \multirow{3}{*}{ Back } & $>$ Armhole & & & & \\
\hline & $>$ Upper arm & & & & \\
\hline & $>$ Appearance & & & & \\
\hline \multirow{3}{*}{ Side } & $>$ Shoulder point & & & & \\
\hline & $>$ Sleeve center line & & & & \\
\hline & $>$ Upper arm & & & & \\
\hline
\end{tabular}




\begin{tabular}{|c|c|c|c|c|}
\hline \multirow{2}{*}{ Evaluation Points } & \multicolumn{4}{|c|}{ Sleeve } \\
\hline & Very good & Good & Poor & Notes \\
\hline$>$ Appearance & & & & \\
\hline Overall appearance & & & & \\
\hline
\end{tabular}

\section{References:}

[1] A. Beazley, T. Bond, Computer-Aided Pattern Design and Product Development, WileyBlackwell, (2003), USA.

[2] B. Emodi, Measure it right in threads magazine, Taunton Press, (2013), USA

[3] B. Reda, 2018 Ph.D. Thesis "A comparative study between Profili and Helen Armstrong Patterns and to make use of them in the implementation of the Egyptian women's jacket", (Faculty of Applied Arts - Damietta University)

[4] D. Datta, P. Seal, Various approaches in pattern making for garment sector, Journal of Textile Engineering \& Fashion Technology, 4 (1): 2018 (29-34)

[5] Egyptian Standard Specifications, Dimensions of the Egyptian human body, part two: girls and women's bodies away, Egyptian General Authority for Standardization and Quality, The Egyptian Arabic Republic, (2004) 16-18

[6] F. Burgo, Modellism tecnica del modello sartoriale e industriale, Moda Burgo, (2004), Italy

[7] G. Cooklin, Pattern cutting for women's outerwear, Wiley-Blackwell, (1994), USA

[8] J. Kasambala, An exploration of female consumers perceptions of garment fit and the effect of personal values on emotions, University of South Africa, (2013)

[9] J. Ward, M. Shoben, Pattern Cutting and Making Up: The Professional Approach Paperback, Routledge, (1987), UK

[10] K.LaBat, Consumer satisfaction/dissatisfaction with the fit of ready-to-wear clothing, University of Minnesota, (1987)

[11] K. Mohamed, $2004 \mathrm{Ph} . \mathrm{D}$. Thesis, Novel flat pattern by using modeling technique and its application on different fabrics, (Home Economics - Textile and Clothing. Women's College, Ain Shams University)

[12] K. Mohamed, H. Zakaria, H. Mahmoud, Comparative Study Between Two Methods of Easy Fitting Block Pattern of Blouse to Fit the Egyptian Women's Bodies. Journal of Studies and Searches of Specific Education 6: (2020) 351-373

[13] K. Shin, The origins and evolution of the bra, The University of Northumbria at Newcastle, (2009)

[14] L. Hollahan, How to use adapt and design sewing patterns, Paul Carslake, (2010), London 
[15] L. Kinchen, M. Deane, Clothing for moderns, Macmillan, (2008), New York.

[16] M. Barra, J. Ralston, Fit Made Easy: Dress Forms \& Fitting Secrets Revealed, CreateSpace Independent Platform, (2006), Italy

[17] M. Geetha, Commercial garment designing and making. Kamala Nehru Polytechnical College for Women, 2005.

[18] M. Ledbetter, L. Thiel, Tailoring: Traditional and contemporary techniques, Reston, (1981), USA

[19] N, Bray, Dress Fitting: Basic Principles and Practice, Wiley-Blackwell, (2003), USA

[20] N. MacDonald, Principles of Flat Pattern Design, Fairchild Books, (2010), USA

[21] N. Zieman, Pattern fitting with confidence, Krause, (2009), London

[22] P. Brown, J. Rice, Ready-to-Wear Apparel Analysis, Pearson, (2014), UK

[23] P. Stringer, Pattern drafting for dressmaking, B.T Batsford, (1996), London

[24] P. Susan, K. Elizabeth, Comparison of Test Protocols for Judging the Fit of Mature Women's Apparel. Clothing and Textiles Research Journal, 24(2): (2006) 137-146

[25] S. Al Sakhawy, A Study on corsage of women darts free basic model design methods, International Design Journal, 9 (1): (2018) 131-140

[26] S. Gupta, N. Garg, R. Saini, Textbook of clothing textile and laundry, Kalyani, (2009), New Delhi

[27] S. Hwang, Three-dimensional body scanning system with potential for use in the apparel industry, Faculty of North Carolina State University, (2011), North Carolina

[28] S. Mostafa, Introduction of a new method for constructing the basic pattern for women by comparing three methods, Journal of Home Economics, 22: (2014), 173 -198

[29] V. Cock, Dressmaking Simplified, Wiley-Blackwell, (1991), Canada

[30] W. Aldrich, Metric Pattern Cutting, Blackwell, (1994), USA

[31] W. Aldrich, Metric Pattern Cutting for Women's Wear, Blackwell, (2008), UK 


\section{الملخص العربى}

بناء طريقة جديدة لنموذج أساسي سهل البناء ليناسب جسم المرأة المصرية و مقارنتها بطريقة بورجو

$$
\text { حنين محمود محمد سعيد*، خالد محمد أحمد عبده، هبة زكريا أبو حشيش }
$$

الملخص العربي:

يعد بناء النموذج الأساسي هي الخطوة الأساسية التي يمكن أن تغطي جميع أنواع الأجسام ، وبالتالي يمكن تطبيقها على أب تصميم و أي نوع من أنواع الملابس. لذلك ، فإن ضبط بناء النموذج الأساسي يزيد من جودة القطع الملبسية. عملية بناء النموذج الأساسي لوني عملية تستدعي الجانب الفني في تحليل التصميم بدقة وفهم نوع النسيج المستخدم وبنيته، وبين الجانب العملي في أخذ قياسات الجسم بدقة و إضافة مقدار مناسب من مقدار الر احة لملائمة جميع المقاسات، ويعطي التأثير المناسب من حيث الضبط و الراحة. لذلك ركز البحث على بناء نموذج سهل البناء للكورساج (نموذج خالي من البنسات) ليناسب جسم المر أة المصرية. و قد أظهرت نتيجة هذا البحث أن الطريقة (المقترحة ) أفضل من طريقة فيرناندو بورجو (ب). على هذا النحو ، أوصت الدر اسة بأهمبة در اسة النماذج الأساسية سهلة البناء ودر اسة صنع النماذج كأحد العو امل الرئيسية لجودة المنتج النهائي. 